\title{
Determining shallow aquifer vulnerability by the DRASTIC model and hydrochemistry in granitic terrain, southern India
}

\author{
N C Mondal ${ }^{1, *}$, S Adike ${ }^{2}$, V S Singh ${ }^{1}, \mathrm{~S} \mathrm{Ahmed}^{1}$ and K V Jayakumar ${ }^{3}$ \\ ${ }^{1}$ Earth Process Modeling Group, CSIR-National Geophysical Research Institute, Hyderabad 500 007, India. \\ ${ }^{2}$ Rural Water Supply \& Sanitation, Mahaboobnagar, Telangana, India. \\ ${ }^{3}$ Water $\mathcal{G}$ Environmental Division, Department of Civil Engineering, National Institute of Technology, \\ Warangal 506004 , India. \\ ${ }^{*}$ Corresponding author. e-mail: ncmngri@gmail.com
}

Received: 28 October 2016 / Revised: 20 January 2017 / Accepted: 15 March 2017 /

Published online: 2 September 2017

Shallow aquifer vulnerability has been assessed using GIS-based DRASTIC model by incorporating the major geological and hydrogeological factors that affect and control the groundwater contamination in a granitic terrain. It provides a relative indication of aquifer vulnerability to the contamination. Further, it has been cross-verified with hydrochemical signatures such as total dissolved solids (TDS), $\mathrm{Cl}^{-}, \mathrm{HCO}_{3}^{-}, \mathrm{SO}_{4}^{2-}$ and $\mathrm{Cl}^{-} / \mathrm{HCO}_{3}^{-}$molar ratios. The results show four zones of aquifer vulnerability (i.e., negligible, low, moderate and high) based on the variation of DRASTIC Vulnerability Index (DVI) between 39 and 132. About 57\% area in the central part is found moderately and highly contaminated due to the 80 functional tannery disposals and is more prone to groundwater aquifer vulnerability. The high range values of TDS $(2304-39,100 \mathrm{mg} / \mathrm{l}) ; \mathrm{Na}^{+}(239-6,046 \mathrm{mg} / \mathrm{l})$ and $\mathrm{Cl}^{-}(532-13,652 \mathrm{mg} / \mathrm{l})$ are well correlated with the observed high vulnerable zones. The values of $\mathrm{Cl}^{-} / \mathrm{HCO}_{3}^{-}$(molar ratios: 1.4-106.8) in the high vulnerable zone obviously indicate deterioration of the aquifer due to contamination. Further cumulative probability distributions of these parameters indicate several threshold values which are able to demarcate the diverse vulnerability zones in granitic terrain.

Keywords. Shallow aquifers; DRASTIC model; hydrochemical signatures; vulnerability assessment; granitic terrain; southern India.

\section{Introduction}

The aquifer vulnerability has been defined using DRASTIC model (Albinet and Margat 1970; Aller et al. 1987). The word 'DRASTIC' is an acronym abbreviated for seven parameters such as depth of water table $(\mathrm{D})$, net recharge $(\mathrm{R})$, aquifer media (A), soil media $(\mathrm{S})$, topography $(\mathrm{T})$, impact of vadose zone (I) and hydraulic conductivity (C). It is the measure of possibility of pollution or contamination at the ground level to reach an aquifer. Numerous schemes have been developed for assessing vulnerability. The DRASTIC modeling is preferred among many other techniques as it has the capacity to show all hydrogeological properties in the final map. Also, it can 
be feasibly inferred for the results by plotting groundwater contaminations such as nitrate, chloride, TDS, etc. (Prasad et al. 2011; Kaliraj et al. 2015).

Aller et al. (1987) was the first to introduce the DRASTIC modeling under US Environmental Protection Agency (USEPA). Later, the DRASTIC technique was applied to assess the groundwater vulnerability (Moulton 1992; Kim and Hamm 1999; Al-Rawabdeh 2013). The entire study area is divided into different vulnerable zones, viz., negligible, medium, moderate and high. Attempts have been made to improve over the technique by comparing the results with the groundwater pollution (Prasad et al. 2008; Javadi 2011; Prasad and Shukla 2014; Kaliraj et al. 2015). An analytical hierarchy process is applied in DRASTIC model to fix the weights and ratings parameters (Bai et al. 2012; Tirkey et al. 2013). An advanced technique namely map removal sensitivity and single parameter model are used by applying sensitivity analysis to delineate the sensitive parameter among seven DRASTIC parameters (Insaf et al. 2005; Mamadou and Zhonghua 2010; Salwa et al. 2011; Akhtar and Tang 2014). In Indian context, the DRASTIC model has been widely used for groundwater assessment in Fatehgarh Sahib district of Punjab (Kumar et al. 2016), Mewat district of Haryana (Mehra et al. 2016), Lucknow city and western Uttar Pradesh (Khan et al. 2014; Singh et al. 2015), a part of Gangetic plains in Bihar and Uttar Pradesh (Saha and Alam 2014), Mandla district of Madhya Pradesh (Prasad and Shukla 2014), Kharun Basin of Chhattisgarh (Sinha et al. 2016), Ranchi district of Jharkhand (Iqbal et al. 2015), West Bokaro Coalfield of Ramgarh district, Jharkhand (Tiwari et al. 2016), Nalgonda district of Telangana (Brindha and Elango 2015), Mysore city of Karnataka (Lathamani et al. 2015), southwest coast of Kanyakumari, Kancheepuram, Tuticorin districts and Mettur region of Tamil Nadu (Srinivasamoorthy et al. 2011; Kumar et al. 2014; Selvam et al. 2014; Kaliraj et al. 2015).

In recent years, it has been observed that severe contamination of surface and groundwater affects the health of rural farming community and nearby livelihood (Mondal and Singh 2010, 2011). In such a case, the uncontrolled discharge of untreated effluents of tanneries is found to be primary cause of pollution (figure 1). They turned the fertile land unfertile. Local masses suffered from occupational diseases such as asthma, chromium ulcers and skin diseases (Mondal and Singh 2005;
Mondal et al. 2005). In such a situation, the environmental degradation coupled with poor management of water resources, and soon there may be crisis for potable water. During the past few decades, groundwater has been contaminated at different depths due to an increase in industrialization (Mondal and Singh 2011). Due to increased industrialization, atmospheric air is also getting polluted. Pollution in the air, precipitates to the ground along with rains. This leads to pollution of groundwater resources. In addition, industrial waste and the municipal solid wastes have also polluted surface and groundwater (Mondal and Singh 2010).

Processing of leather requires large amount of freshwater and various chemicals like lime, sodium carbonate, sodium bicarbonate, common salt $(\mathrm{NaCl})$, fat liquors, chrome sulphate, dyes and vegetable oils. In fact, every $10 \mathrm{~kg}$ of raw skin requires about 350 liters of freshwater till it completes the process (Mondal and Singh 2010). Since the water sources are very low in the area, they have been overexploited for the very low water table depth (ranges: 2.3-25.9 m, below ground level, bgl). Also, the chemicals contaminate the agricultural lands nearby. The wastewater discharged for $100 \mathrm{~kg}$ of skin varies from 3000 to 3200 litres (Mondal et al. 2005). Tannery waste is primarily characterized by bulk amount of salt, strong colour, high $\mathrm{pH}$, BOD and dissolved solids. The effluents when discharged into the ground, affect the groundwater table. Also, the effluents which are stuck in the soil pores are pushed forward during rainfall, thereby affecting the groundwater recharge. Not only the chemicals but also the dischargeable wastewater from the tanneries seeps into the ground to affect the net recharge. Since recharge is getting affected, the contamination spreads to other properties associated with the recharge like transmissivity, vadose zone, conductivity, etc. Thus, considering all these parameters, the objectives of this study are 3-fold: (1) assess the vulnerability extent using DRASTIC model in a granitic area, southern India, (2) refine the model by sensitive analysis, and (3) cross-verify with the hydrochemical signatures and the cumulative distribution of the selective parameters.

\section{Materials and methods}

\subsection{Brief description of the study area}

The study area is a drought prone hard rock terrain with an area of about $240 \mathrm{~km}^{2}$ and located 


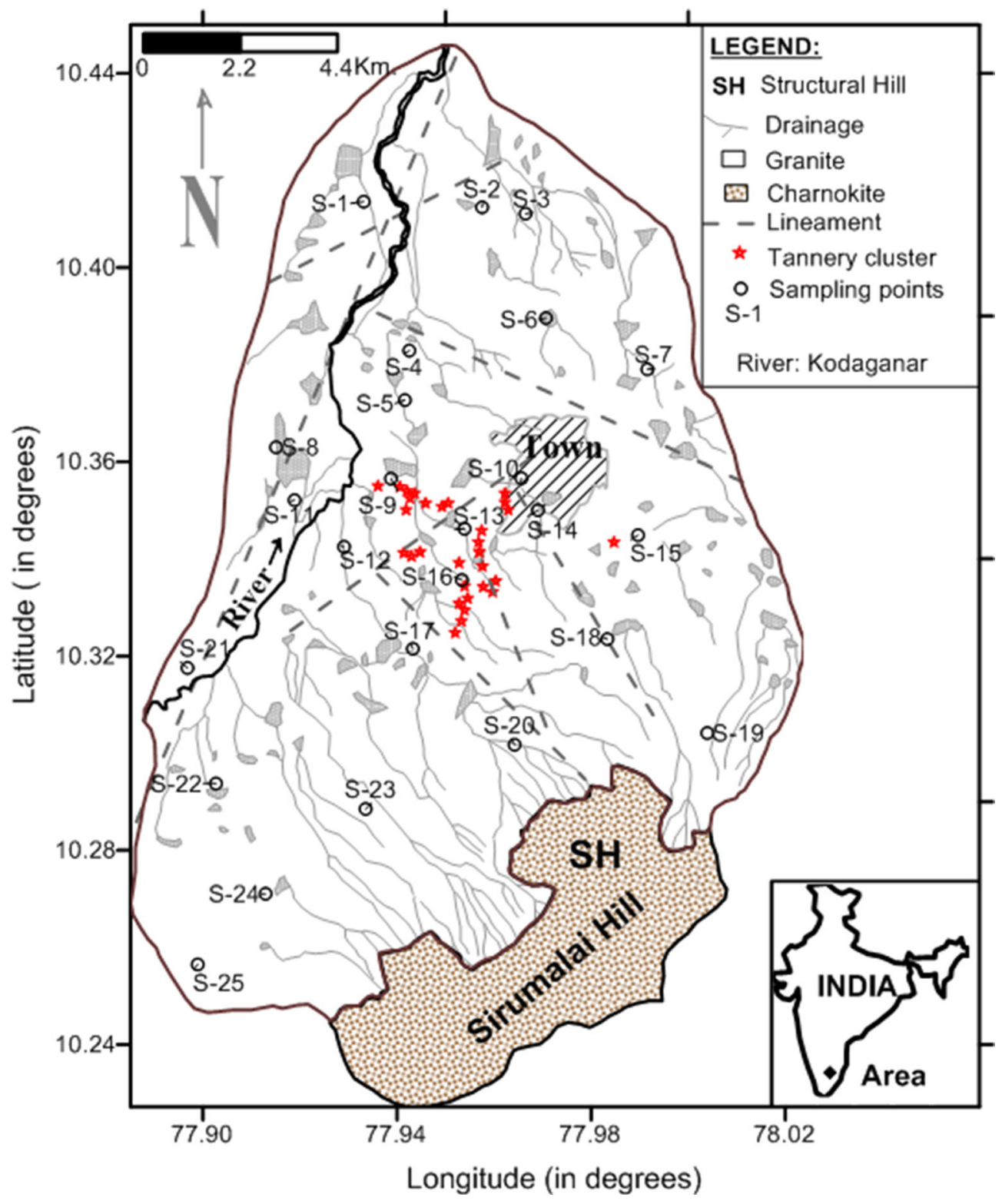

Figure 1. Location of the study area.

in between $10^{\circ} 13^{\prime} 44^{\prime \prime}-10^{\circ} 26^{\prime} 47^{\prime \prime} \mathrm{N}$ latitudes and $77^{\circ} 53^{\prime} 08^{\prime \prime}-78^{\circ} 01^{\prime} 24^{\prime \prime} \mathrm{E}$ longitudes (figure 1). The area is characterized by undulating topography with hills (Sirumalai) located in southern parts, sloping towards north and northeast. The elevation (altitude) in plains ranges from $370 \mathrm{~m}$ (amsl) in the southern part to $230 \mathrm{~m}$ in the northern part (Mondal et al. 2005). No perennial streams exist in the area, except for short distance streams encompassing 2nd and 3rd order drainage (Mondal and Singh 2010). Runoff from rainfall within the area ends in small streams flowing towards the main Kodaganar River. From a period of 19712007, the average annual rainfall is of the order of $905.3 \mathrm{~mm}$.

\subsection{Geological and hydrogeological setup}

The study area is covered with Archean granites and gneisses, intruded by dykes. These rocks are crossed by sets of joints and fractures, which have also caused weathering of coarser rocks. The shallow hard and massive rocks are exposed mostly in the southern part. Red sandy soil is obtained in northern and southern parts of the area whereas black cotton soil occurs in the middle part. The weathered thickness varies from 3.1 to $26.6 \mathrm{~m}$ (Mondal and Singh 2005). Such shallow weathered zones may not be stable sources of groundwater for meeting large demands of groundwater (Singh et al. 2003). There are many lineaments which are 
oriented mainly in the NNE-SSW, NEE-SWW, and NW-SE directions, but the major lineament runs in the NNE-SSW direction for several kilometers situated northwest of Dindigul along Kodaganar River (figure 1). The weathered zone facilitates the movement and storage of groundwater through a network of joints, faults and lineaments, which form conspicuous structural features. Apart from the structural controls on the groundwater movement, the area is covered with pediment and buried pediment on southern and western sides of the area. The other most dominant formation is the charnockite, which is only found in southern and southeastern parts of the Sirumalai hill. This formation is less weathered, jointed or fractured compared to the previous one and can therefore be considered as impermeable (Mondal and Singh 2005).

Groundwater occurs mostly in weathered and fractured zones, which are mainly unconfined in nature at shallow depth and sometimes semi-confined or confined also (Singh et al. 2003). The thickness of weathered zone varies from 3.1 to $26.6 \mathrm{~m}$, acting mainly shallow aquifer and its distribution has been shown in Fench diagram (figure 2), which has been prepared with the help of geophysical survey's results incorporating the well logs and cuttings (Mondal and Singh 2011). These aquifer confining conditions may change rapidly and vary over a wide range from place to place. The thickness of weathered/fractured zone varies over even a small region. Shallow aquifers (extended around $27.68 \mathrm{~m}$, below ground level) are usually phreatic condition, which may not be a stable source for meeting large demands on groundwater, but deeper aquifers (occurred in fractures below the bed rock) are partly-confined/confined, i.e., they are recharged from shallow unconfined aquifers through dug-cum-bore wells/bore wells as water accumulates in dug wells, percolates into confined aquifers through bore wells which are provided in dug wells. Groundwater is being extracted through rope-pulley method from dug well in shallow aquifer and dug-cum-bore and bore wells in deeper aquifers for their needs.

\subsection{Data collection}

Seven DRASTIC parameters like groundwater table, recharge, aquifer discharge, soil types, surface elevation, vadose zone thickness and aquifer properties were collected. The groundwater level, surface elevation, vadose zone thickness and aquifer properties were collected in the field condition from the study area. The depths to groundwater table were measured at 46 wells. Survey was also carried out for the measurement of topography. It was estimated at 600 locations in grid pattern $(200 \times$ $200 \mathrm{~m}$ ) and incorporated in GIS format to produce the topography map. Vadose zone thickness was calculated using the groundwater level data at the existing wells. It varied from 0.52 to $5.35 \mathrm{~m}$. The infiltration rate was reported as $<1.7 \mathrm{~cm} / \mathrm{hr}$ (PWD 2000). Aquifer properties such as transmissivity $(T)$ and storativity $(S)$ were estimated through pumping test at 8 wells (Singh et al. 2003). T values vary from 15 to $200 \mathrm{~m}^{2} /$ day, whereas $S$ values from 0.0000225 to 0.00095 . Aquifer transmissivity is proportional to hydraulic conductivity $(K)$, which is best defined as an exponential function of aquifer resistivity (Mondal et al. 2016a). Therefore, the calculated $T$ values were directly used to prepare transmissivity map of the study area.

The collateral data like groundwater recharge was estimated at six PWD wells by entropy method (Mondal et al. 2012). The recharge rate varies from 3.37 to $11.10 \%$ during the north-east monsoon. The rainfall data was also collected in the year 2001 and it was converted into groundwater recharge which varies from 22 to $69 \mathrm{~mm} /$ year. It was utilized to prepare recharge map for the DRASTIC model. Although granite is the only geology in the entire study area, due to the heterogeneity in hard rock area, its property of the media changes spatially. Thus, the aquifer media, which serves as aquifer, is characterized based on the water level fluctuation (Singh et al. 2003). The water level fluctuation varied from 0.00 to $7.20 \mathrm{~m}$ which was used for the preparation of aquifer media map. The soil map data had been collected from Public Works Departments (PWD 2000).

The groundwater samples were also collected from 25 representative dug wells and dug-cumbore wells (figure 1), which were under use at 0.5 $\mathrm{m}$ below the water table, and were pumped for more than 5 min. Methods of collection and analysis of groundwater samples for the cations and anions analysis followed were essentially the same as given by Brown et al. (1970). Samples were collected in 1-litre capacity polythene bottles. Prior to the collection, bottles were thoroughly washed with diluted $\mathrm{HNO}_{3}$ acid, and then with distilled water in the laboratory before filling bottles with samples. Each bottle was rinsed to avoid any possible contamination in bottling and every other precautionary measure was taken. WTW portable 


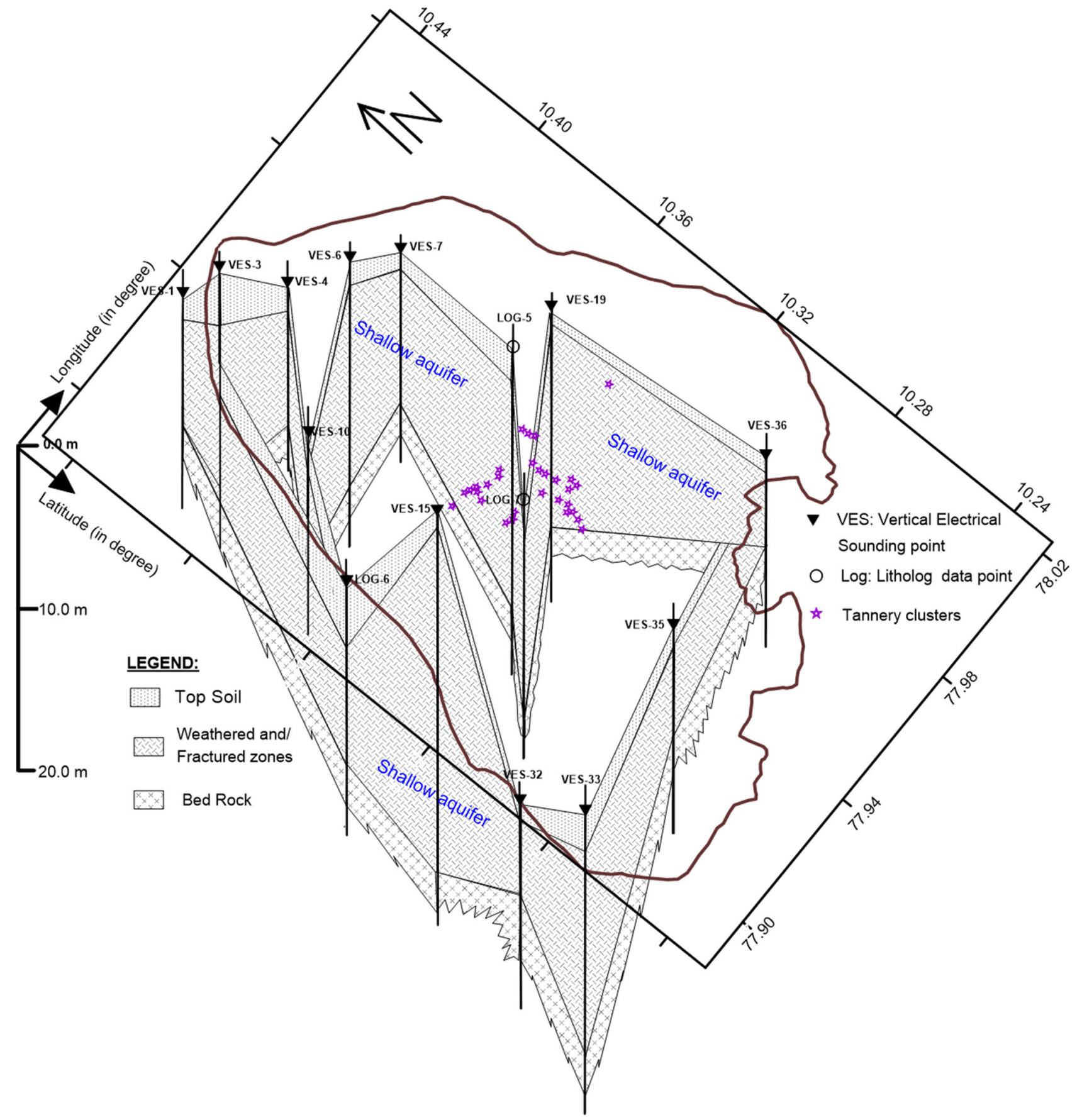

Figure 2. Fence diagram showing shallow aquifer.

$\mathrm{EC}$ and $\mathrm{pH}$ meters also measured hydrophysical parameters, such as $\mathrm{pH}$ and $\mathrm{EC}$, on site. These data were used to verify the vulnerability zones of the DRASTIC model. The summary of the method adopted in this study is presented in a flow chart (figure 3).

\subsection{DRASTIC model}

The DRASTIC modeling was carried out to arrive at groundwater vulnerability zones. The word
DRASTIC is an acronym abbreviated for seven parameters like depth of water table (D), net recharge $(\mathrm{R})$, aquifer media $(\mathrm{A})$, soil media $(\mathrm{S})$, topography $(\mathrm{T})$, impact of vadose zone (I) and hydraulic conductivity (C) (table 1 ). Since these are the functioning parameters in defining the groundwater contamination, mapping and overlapping of these parameters helps in evaluating the degree of susceptibility for groundwater pollution. The parameters in the DRASTIC model were initially divided into ranges for corresponding 


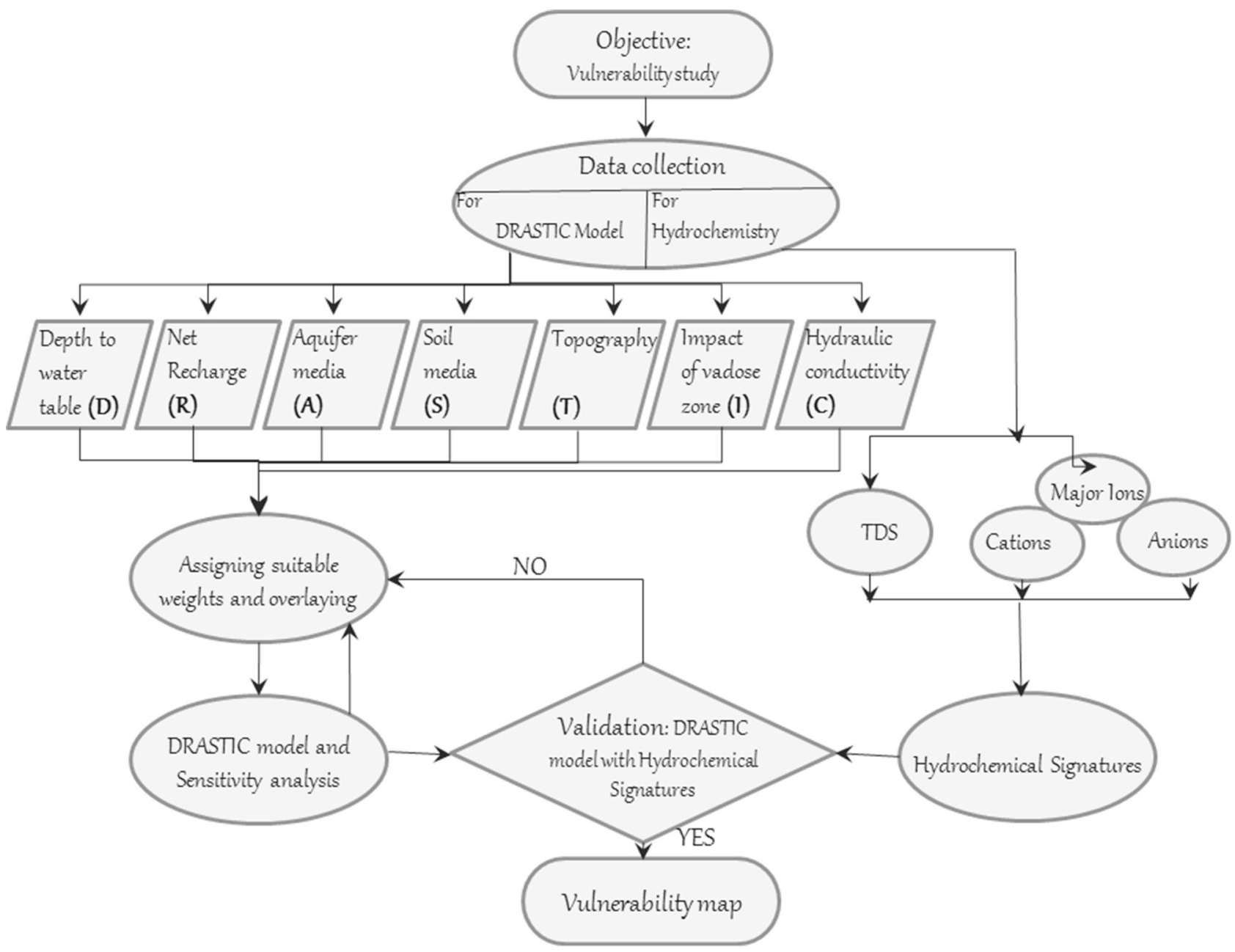

Figure 3. Flow chart reveals about vulnerability evaluation using DRASTIC model coupling with hydrochemical parameters.

hydrogeological settings and these individual ranges should be assigned with a definite rating factor on a scale of $1-10$. The value ' 1 ' symbolizes for negligible vulnerable region and ' 10 ' for high vulnerable region. This was succeeded by assigning weights value for the individual parameter, on a scale of $1-5$, relative to their importance in contributing to the vulnerability. In this study, Delphi approach was adopted in fixing the range, rating and weights. Finally, the DRASTIC vulnerability index was calculated by the formula given below.

$$
\begin{aligned}
\text { DRASTIC Index }= & D_{r} D_{w}+R_{r} R_{w}+A_{r} A_{w} \\
& +S_{r} S_{w}+T_{r} T_{w}+I_{r} I_{w} \\
& +C_{r} C_{w},
\end{aligned}
$$

where capital letters indicate corresponding parameter and suffixes ( $r$ and $w$ ) indicate the assigned rates and weights, respectively.
The above-described system was processed under GIS environment, as it is a platform for thematic layer preparation and mathematical calculations. The choice of this particular software is because of its varied features of storage, retrieval, mapping and analysis of geographic data; spatial features can be stored in a coordinate system (latitude/longitude, state plane, UTM, etc.), which reference a particular place on the earth. Also, its specialty in associating spatial features with descriptive attributes in tabular form and these in the same coordinate system can then be layered together for mapping and analysis. It helps in decreasing the tedious job. The 'Spatial Analyst Tools' from the extension tools of Arc catalog were used. After digitizing the map, seven vector layers were constructed for each parameter. They were then converted into raster form and reclassified by assigning suitable ratings based on their nature. Each of the seven layers was overlapped by the weighted sum tool. The respective weights were 
Table 1. The relative assigned weight (s) of DRASTIC model parameters and its description.

\begin{tabular}{|c|c|c|c|}
\hline Factor $(\mathrm{s})$ & Description & $\begin{array}{l}\text { Relative weight } \\
\text { (after Aller et al. } 1987 \text { ) }\end{array}$ & $\begin{array}{l}\text { Assigned } \\
\text { relative } \\
\text { weight(s) }\end{array}$ \\
\hline Depth to water & $\begin{array}{l}\text { It is the depth from ground surface to the top of } \\
\text { groundwater table, deeper the water level is, the } \\
\text { lesser the chance of contamination }\end{array}$ & 5 & 5 \\
\hline Net recharge & $\begin{array}{l}\text { It is an amount of water which recharges the } \\
\text { aquifer, high amount of recharge carries more con- } \\
\text { taminant }\end{array}$ & 4 & 4 \\
\hline Aquifer media & $\begin{array}{l}\text { It represents the property which defines the aquifer } \\
\text { matrix like discharge, high discharge constitutes to } \\
\text { high contamination }\end{array}$ & 3 & 3 \\
\hline Soil media & $\begin{array}{l}\text { It is the controlling parameter of infiltration, which } \\
\text { represents the soil type, cohesive soils retain the } \\
\text { contaminants than noncohesive soils }\end{array}$ & 2 & 2 \\
\hline Topography & $\begin{array}{l}\text { It represents the slope of land surface, gentle undu- } \\
\text { lations sustain the water in a place forcing water } \\
\text { to percolate into the ground }\end{array}$ & 1 & 1 \\
\hline Impact of vadose zone & $\begin{array}{l}\text { It is the unsaturated part of earth between ground } \\
\text { surface and top of the phreatic zone, lesser the soil } \\
\text { thickness is higher chance of contaminant interac- } \\
\text { tion with the water table }\end{array}$ & 5 & 5 \\
\hline Hydraulic conductivity & $\begin{array}{l}\text { It is the ability of aquifer to transmit water, high } \\
\text { transmissivity injects more contaminants into the } \\
\text { aquifer }\end{array}$ & 3 & 3 \\
\hline
\end{tabular}

allocated to each of the layers. DRASTIC index calculation was performed by default and the final score of DRASTIC index was displayed. This index was then divided into four zones according to their scoring value. A high DRASTIC index indicates high vulnerability.

\subsection{Cumulative probability distribution}

Ample of natural earth processes culminate in hydrochemistry of a complex heterogenous aquifer, but this can be reflected in analytical dataset. The probability distributions are considered to be of great importance in dealing with hydrochemical data (Mondal et al. 2011). In order to discriminate the anomalous population whose chemistry was affected locally by salinization and/or anthropogenic pollution from a background population, cumulative probability distributions of hydrochemical parameters were constructed. In particular, probability density functions of TDS, $\mathrm{Na}^{+}, \mathrm{Cl}^{-}$and $\mathrm{SO}_{4}^{2-}$ concentrations were examined in order to group collected samples on the basis of saline water mixing and anthropogenic pollution as the study area is affected by the untreated tannery industries. If a chosen groundwater quality parameter was affected by a single process, the probability distribution of its concentration formed a unimodal normal or log-normal distribution (Tennant and White 1959). The cumulative probability distribution was then linear on a probability paper. If the plots of a groundwater quality parameter did not form a linear distribution, the parameter was considered to be affected by more than one population (process). For such a case, each population was differentiated by the intersection points of two neighbouring linear populations (Sinclair 1974; Mondal et al. 2016b). Similarly, logprobability plots were adapted here to identify the vulnerability strategies in the study area.

\section{Results and discussion}

\subsection{DRASTIC model}

Equation (1) as discussed above was fitted in ArcGIS 10.1 software after preparing the DRASTIC maps. The weights of each DRASTIC factor was assigned with respect to the other for estimating the relative importance of each 
factor (Aller et al. 1987). Although, these factors are site specific, each factor has been assigned a relative weight ranging from 1 to 5 (table 1 ). The most significant weightages (5) were given to depth to the water table and impact of vadose zone, whereas comparatively least weightage (1) had been assigned to the topography. Nonetheless the ratings have a range for each DRASTIC factor with respect to others, and have been assigned based on the hydrogeological sense prevailing in the

Table 2. GIS-based DRASTIC model parameter rating(s) for the vulnerability study.

\begin{tabular}{|c|c|}
\hline Parameter(s) & Rating(s) \\
\hline \multicolumn{2}{|c|}{ Depth to water table (m, bgl) } \\
\hline $2.30-9.52$ & 10 \\
\hline $9.53-12.20$ & 8 \\
\hline $12.21-15.07$ & 6 \\
\hline $15.08-18.40$ & 4 \\
\hline $18.41-25.90$ & 2 \\
\hline \multicolumn{2}{|c|}{ Net Recharge (mm/year) } \\
\hline $22.42-31.91$ & 2 \\
\hline $31.92-38.12$ & 4 \\
\hline $38.13-42.50$ & 6 \\
\hline $42.51-51.27$ & 8 \\
\hline $51.28-64.96$ & 10 \\
\hline \multicolumn{2}{|c|}{ Aquifer media (where $\Delta \mathrm{WL}$ in Zone: in $\mathrm{m}$ ) } \\
\hline $0.00-1.50$ & 2 \\
\hline $1.51-3.00$ & 4 \\
\hline $3.01-4.50$ & 6 \\
\hline $4.5-6.00$ & 8 \\
\hline $6.00-7.20$ & 10 \\
\hline \multicolumn{2}{|l|}{ Soil media } \\
\hline Red sandy soil & 5 \\
\hline Black cotton soil & 1 \\
\hline \multicolumn{2}{|c|}{ Topography (m, amsl) } \\
\hline $230.01-258.43$ & 10 \\
\hline $258.44-283.58$ & 7 \\
\hline $283.59-308.17$ & 5 \\
\hline $308.18-334.96$ & 3 \\
\hline $334.97-369.39$ & 1 \\
\hline \multicolumn{2}{|c|}{ Impact of vadose zone (m) } \\
\hline $0.52-1.41$ & 10 \\
\hline $1.42-1.90$ & 8 \\
\hline $1.91-2.51$ & 6 \\
\hline $2.52-3.59$ & 4 \\
\hline $3.60-5.35$ & 2 \\
\hline \multicolumn{2}{|c|}{ Transmissivity (m²/day) } \\
\hline $15.00-51.27$ & 2 \\
\hline $51.28-81.02$ & 3 \\
\hline $81.03-115.83$ & 5 \\
\hline $115.84-156.73$ & 7 \\
\hline $156.74-199.96$ & 9 \\
\hline
\end{tabular}

study area. The ratings, which varied from 1 to 10, have been assigned for the DRASTIC factor as per the specific hydrogeological knowledge. Specified ratings (table 2) were given for different ranges. It shows the weights portioned for seven parameters of DRASTIC model and ratings for individual range.

\subsubsection{Depth to water table}

Depth to groundwater table is a significant factor in DRASTIC modeling as it affects the vertical travel time of contaminant from surface poundage (Stigter et al. 2006). It is the surface where the water pressure head is equal to the atmospheric pressure (pressure where gauge pressure is zero). Water table was collected at 46 wells; 25.90, 2.30 and $11.97 \mathrm{~m}$ are the maximum, minimum and average values of the dataset, while $5.28 \mathrm{~m}$ is the standard deviation. The groundwater level contours were interpolated with the help of kriging method. Highest rating (10) was assigned to low water table locations (range: $2.30-9.52 \mathrm{~m}$, in table 2) as it is inversely related to the groundwater contamination. If the depth to water level is low from ground surface, then the time of travel for pollutant to reach the water table is less. Hence, it was assigned with highest rating (10). The water table contour map shown in figure 4 gives realtime demarcation in the experimental site. Since there are high hills located in the south-east region, there was comparatively deeper water table and runoff from the hills spreads over the hills foot area. The depth gradually decreases towards central part where the tannery clusters are located (figure 1).

\subsubsection{Recharge}

Recharge basically represents the amount of water that infiltrates into the ground. High recharge indicates high infiltration. As the infiltration contains pollutants, the rate of contamination increases with high recharge. Hence, a proportional rating has been assigned for the recharge values as a high recharge implies high contamination infiltrated into the ground. Since the DRASTIC model was developed for uniform rainfall distribution and natural land surfaces, it is not applicable for the city Dindigul. The area has very low degree of precipitation and moderate undulations (Mondal and Singh 2012a). Thus, the monsoon data from January 1973 to December 2007 has been considered and the 


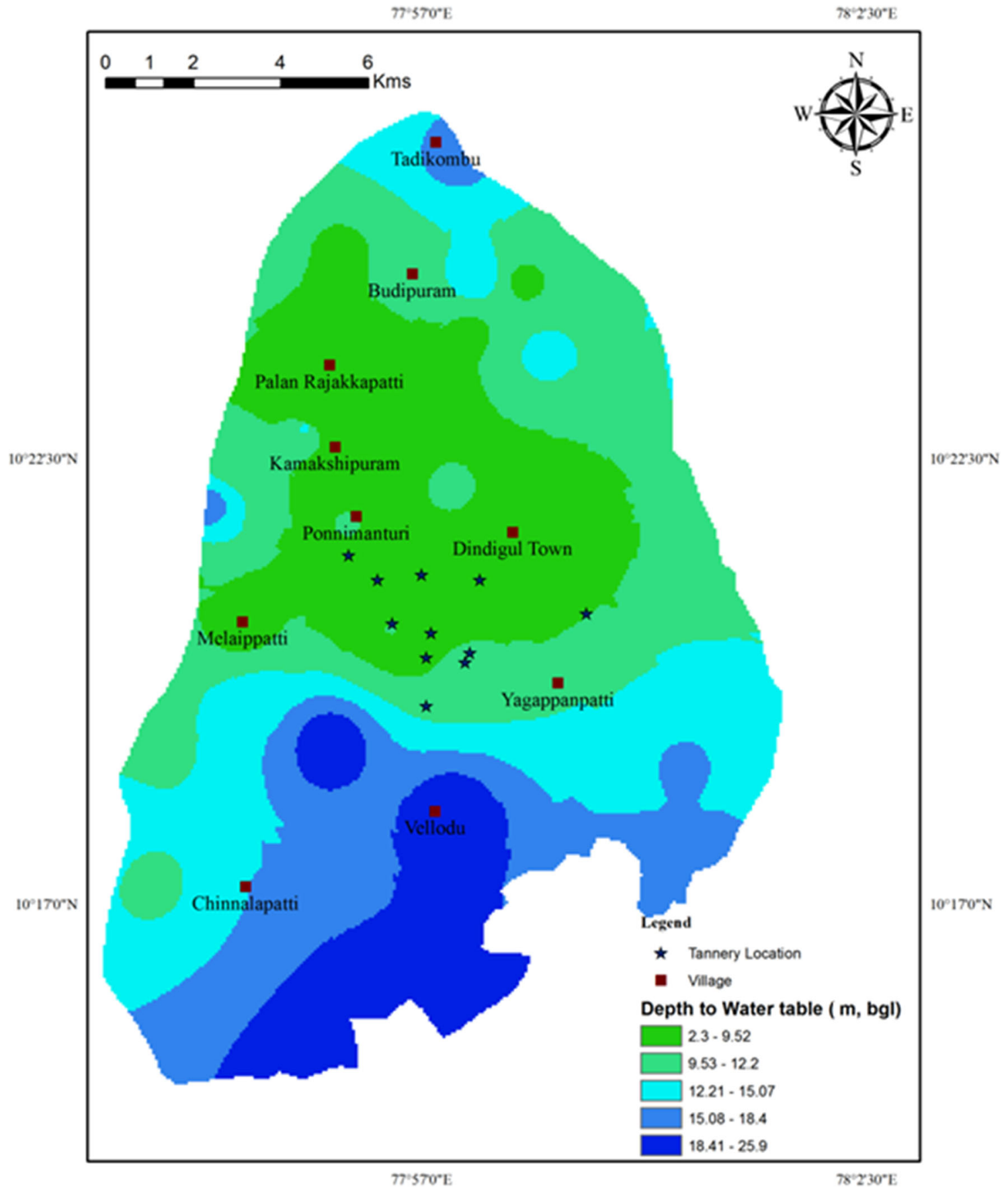

Figure 4. Depth to groundwater level contours (in $\mathrm{m}, \mathrm{bgl}$ ) in unconfined aquifer in the study area.

recharge has been estimated by entropy method (Mondal et al. 2012). This has been extracted from six wells. The maximum, minimum and average values of recharge were found to be $68.98,22.42$ and $44.17 \mathrm{~mm} /$ year, respectively. The recharge is high in north-east corner and gradually decreases at the middle of north-eastern part due to the presence of black cotton soil. Then it increases towards south-western part (figure 5). The recharge mainly deviates due to topography variation and hydrogeological setting in the area (Mondal and Singh 2004).

\subsubsection{Aquifer media}

Aquifer media map is considered to represent the saturated zone which controls the pollution attenuation processes. The purpose of this map is to produce a rating based on the water level 


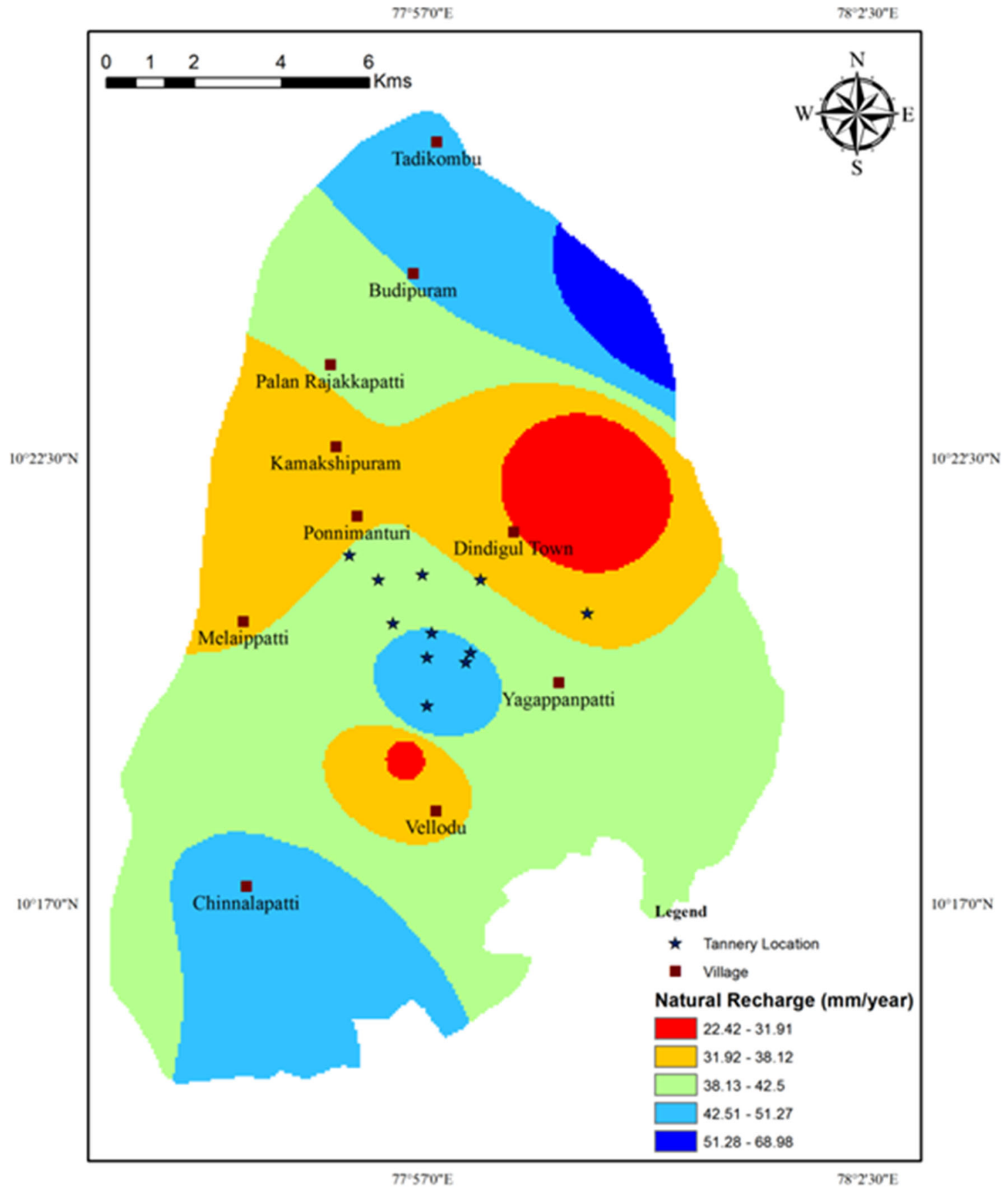

Figure 5. Recharge rate ( $\mathrm{mm} /$ year) distribution in the study area.

fluctuation of aquifer media. The aquifer media map (figure 6) of the study area has been prepared by estimating the water level fluctuation in the field condition (Singh et al. 2003). The change of water level varies from 0.00 to $7.20 \mathrm{~m}$. High groundwater level fluctuation allows more contaminants to enter the aquifer. Therefore, a high fluctuation (range: $6.00-7.20 \mathrm{~m}$ ) will yield a high vulnerability rating (figure 6). The aquifer fluctuation is high in the northern and north-western parts and decreases spatially on either direction.

\subsubsection{Soil media}

Soil media refers to the upper most portion of vadose zone characterized by significant biological activity (Aller et al. 1987). In this study, only the upper weathered zone has been considered. Soil 


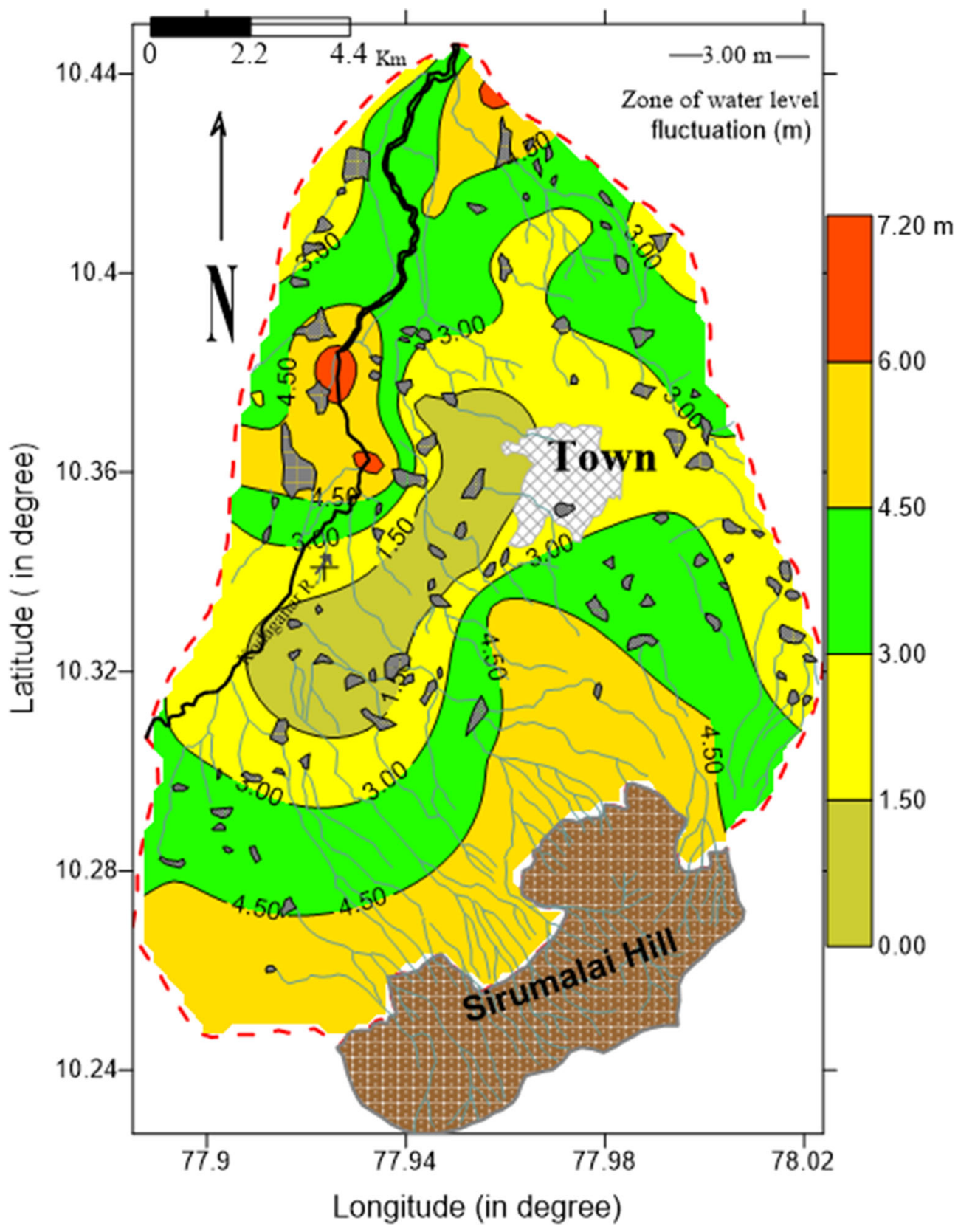

Figure 6. Aquifer media map in the study area.

has a significant impact on the amount of recharge which can infiltrate into the ground and hence, on the ability of a contaminant to move vertically into the vadose zone. Moreover, where the soil zone is fairly thick, the attenuation process of filtration may be quite significant. The soil rating of the study area is shown in figure 7 . Since black cotton soils are cohesive and aquicludes in nature, lowest rating (1) was assigned when compared to red sandy soils (highest rating: 5), where yielding and transmission of water is better when compared to black cotton soils. Black cotton soils occupy the central part of the area leaving the northern- most and southern-most sites to the red sandy soils.

\subsubsection{Topography}

Topography refers to the slope and slope variability of land surface. It helps to control the likelihood that a pollutant will runoff or remain on the surface long enough to infiltrate. It has a significant role in groundwater vulnerability. In case of gentle slope, the contaminant is less likely to move with runoff and more likely to get infiltrated. In the present study, topography measurements were 


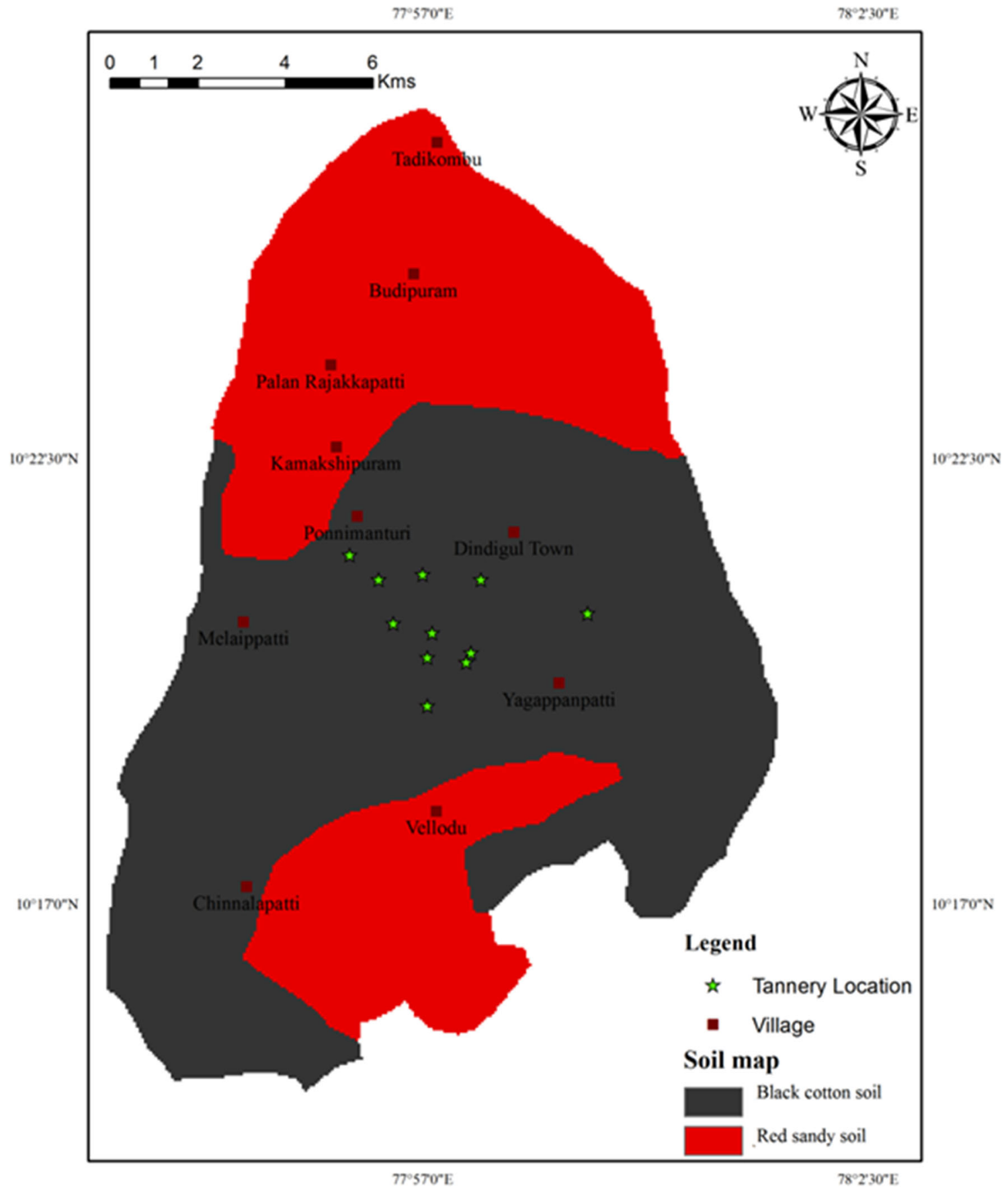

Figure 7. Soil distribution of the study area.

done in the field condition and it varies from 230 $\mathrm{m}$ (amsl) in the northern part to $370 \mathrm{~m}$ (amsl) in the southern part. The ratings were used for the analysis as presented in table 2 and shown in figure 8 .

\subsubsection{Impact of vadose zone}

The vadose zone, also termed the unsaturated zone, is the part of Earth between land surface and the top of phreatic zone, the position at which the groundwater (the water in the soil's pores) is at atmospheric pressure. Hence, the vadose zone extends from the top of the ground surface to the water table. But this table is being fluctuated seasonally and year-wise in any watershed. The infiltrated water reaches the groundwater through this zone. However, when evaluating the model, the word has been expanded to include both the vadose zone and any saturated zones which 


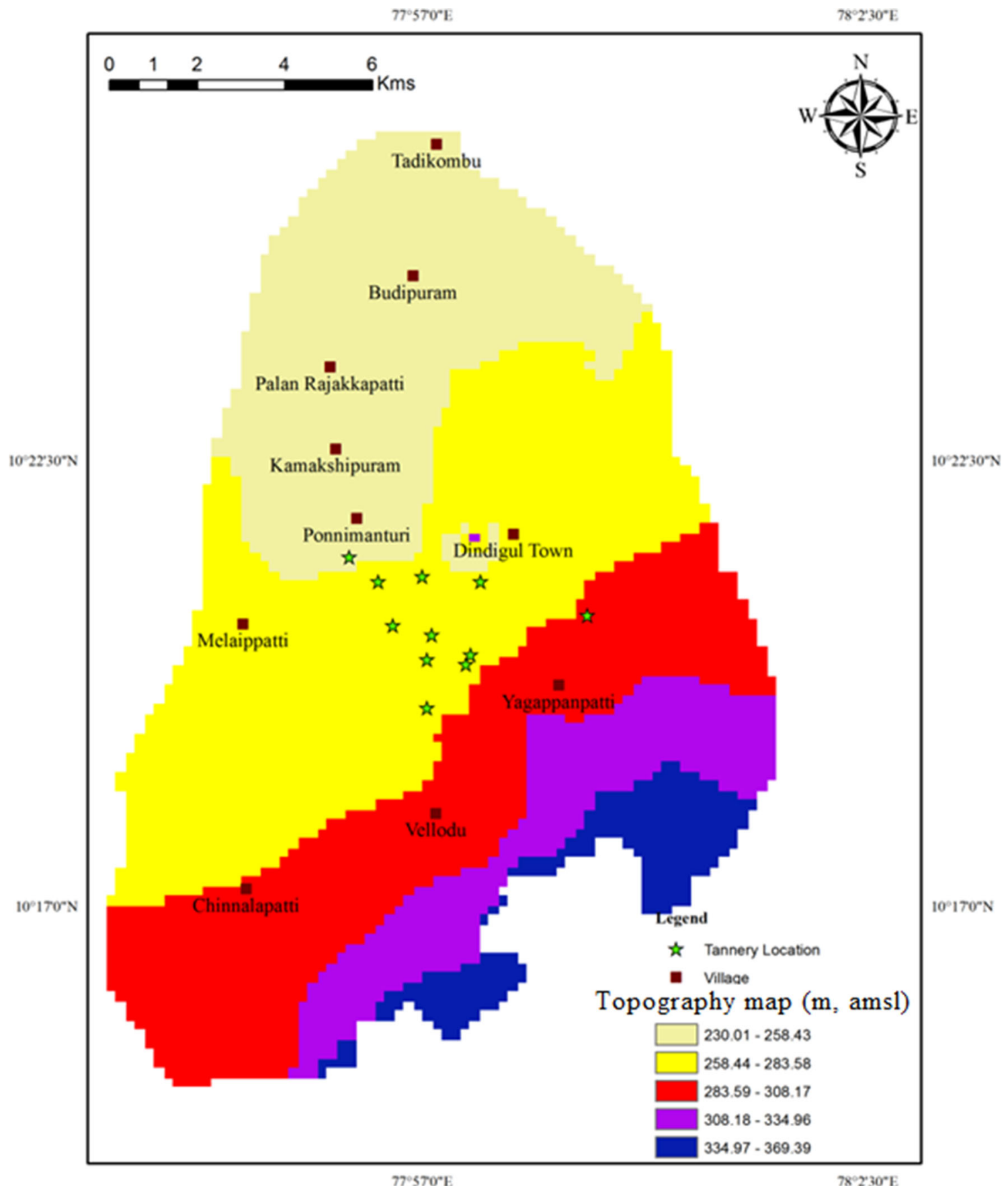

Figure 8. Topography pattern in the study area.

overlie the shallow aquifer. The vadose zones were considered as the depth of regional average water level (bgl) measured in the last 3-4 decades at the PDW wells. It ranges between 0.52 and $5.35 \mathrm{~m}, \mathrm{bgl}$ with an average of $1.59 \mathrm{~m}$ in the study area.

The aquifer media controls the path length and routing as the water flows into the aquifer. Thicker the zone, longer is the path length and thus affecting the travel time of pollutant in groundwater. Hence, an inversely proportional relation has been given to the vadose zone map, i.e., low rating $(=2)$ to the thicker vadose area (range: $3.60-5.35 \mathrm{~m}$ ). Low to medium thickness ranges all over the area were considered except at few places where the thickness range is more as shown in figure 9 .

\subsubsection{Conductivity}

Conductivity represents the property of aquifer to transmit water. High groundwater flow rate represents high contaminant advection; hence a high rating was assigned to high conductivity 


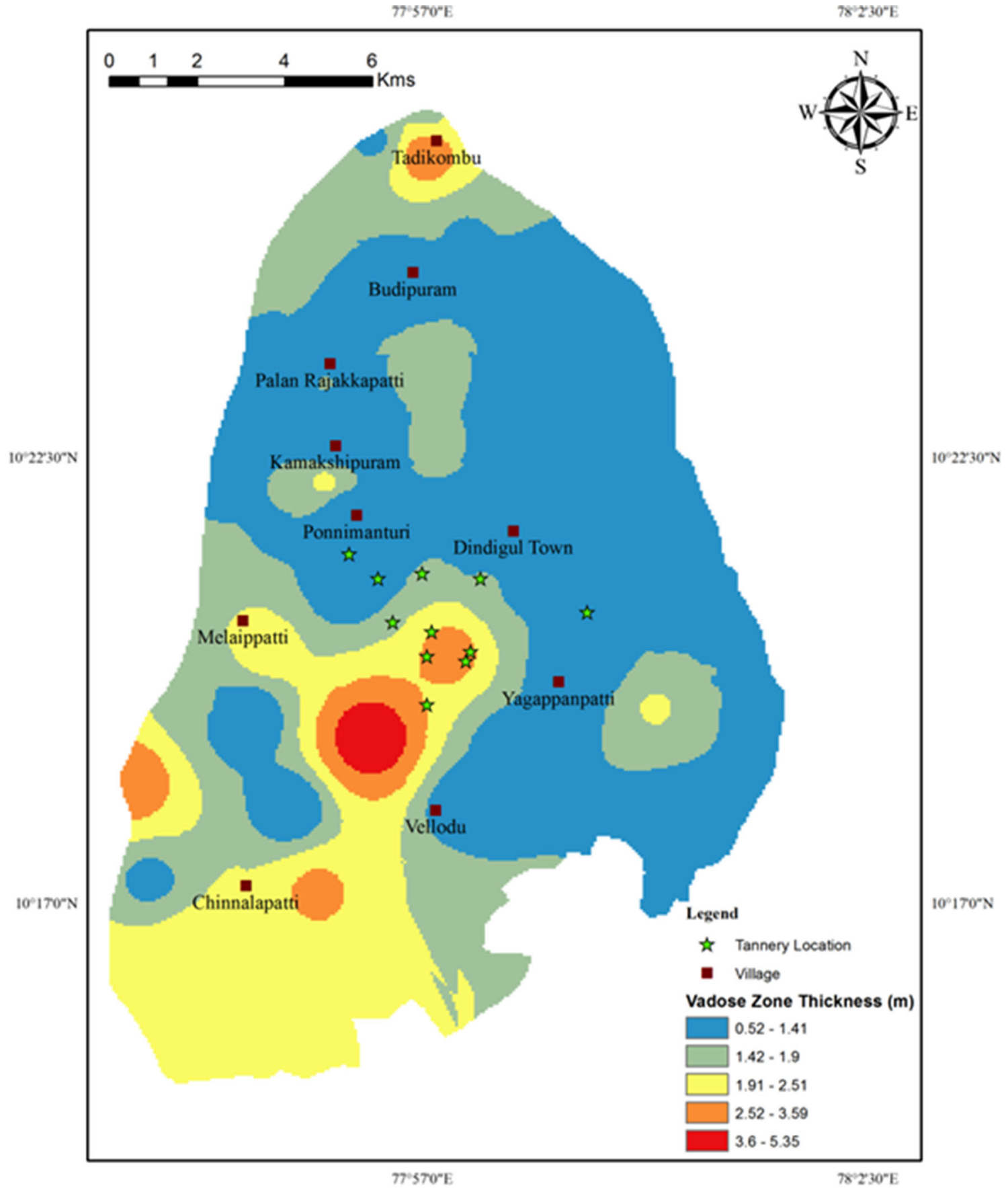

Figure 9. Vadose zone thickness distribution in the study area.

zone. Since hydraulic conductivity is directly proportional to transmissivity, these are utilized for the DRASTIC model. The values range from 15.00 to $199.96 \mathrm{~m}^{2} /$ day, while $84.31 \mathrm{~m}^{2} /$ day is an average of the dataset in the study area. A low transmissivity zone (range: $15.00-51.27 \mathrm{~m}^{2} /$ day) exists at foot of the hills at which the rating was assigned as ' 2 '. It increases spatially to a high value in northeastern part as shown in figure 10 and accordingly assigned the ratings (table 2 ).

\subsubsection{Vulnerable map using the DRASTIC model}

The attribute layers for seven parameters of DRASTIC model were assembled in GIS format (using ArcGIS 10.1). Necessary computations were executed in raster format and seven maps were generated based on the rating system. Finally, DRASTIC map was divided into different classes. In the created seven thematic layers, each pixel was reclassified to a rating value with some reference 


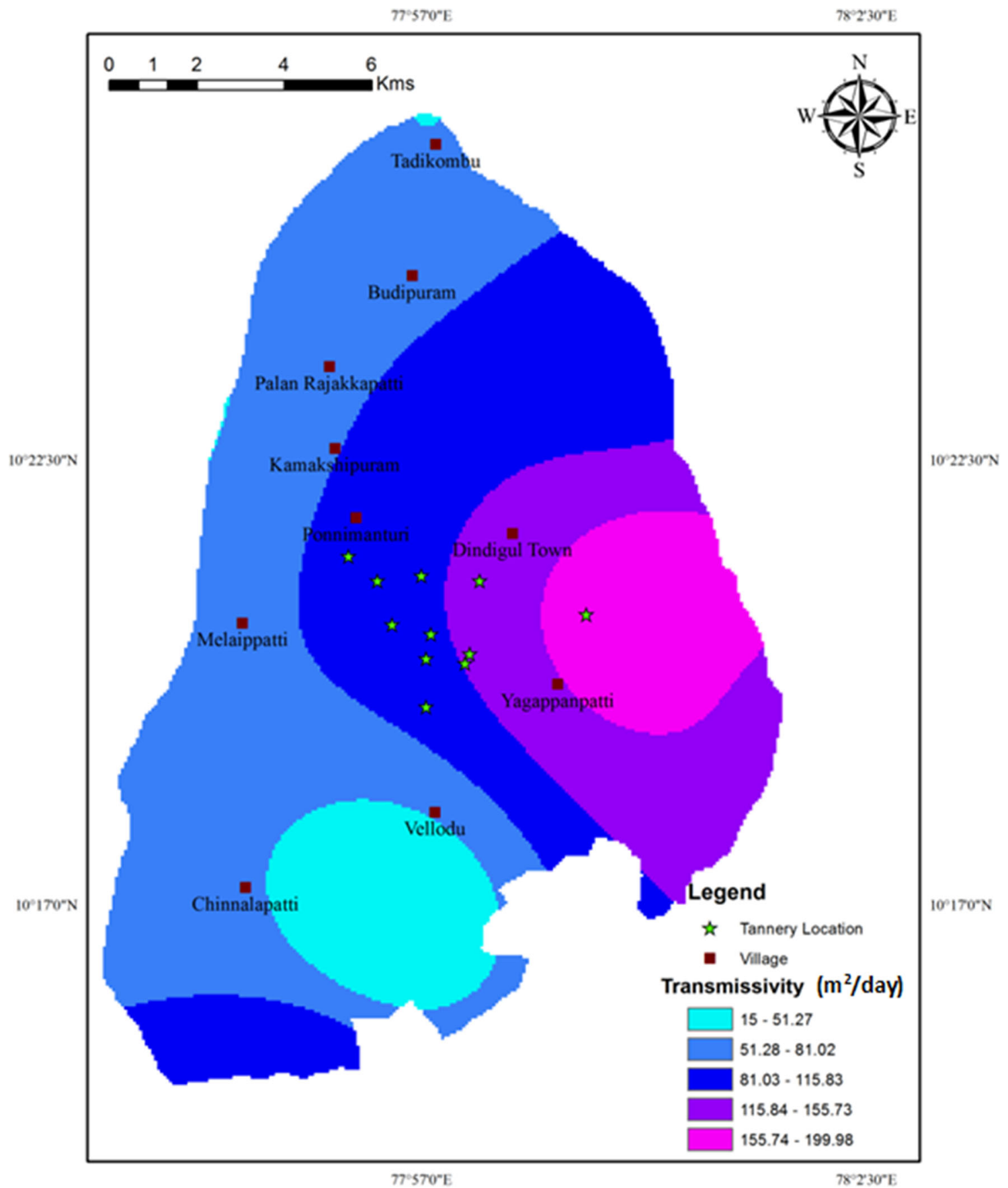

Figure 10. Transmissivity distribution in the study area.

or by Delphi method. The reclassification tool in spatial analyst tool box was used to reclassify each pixel. These reclassified maps were overlaid by the weighted sum tool in the spatial analyst tool box. The process of multiplying reclassified rating of each pixel with the weight given to definite parameter was carried out. Finally, the vulnerability index or DRASTIC index was calculated. Total DRASTIC index varied from 39 to 132 for the vulnerability. The resulted index was divided into four equal groups (Aller et al. 1987). Small numbers indicate low vulnerability potential and large numbers were related to those areas that have high vulnerability in respect to pollution. They represent on a DRASTIC map (figure 11) and the corresponding values for each point were also extracted.

DRASTIC vulnerable map (figure 11) shows that about $103.2 \mathrm{~km}^{2}(43 \%)$ of the area lies between low to negligible risk of pollution zone but the remaining about $136.8 \mathrm{~km}^{2}(57 \%)$ is occupied by moderate risk to high risk of pollution zone (table 3 ). The 


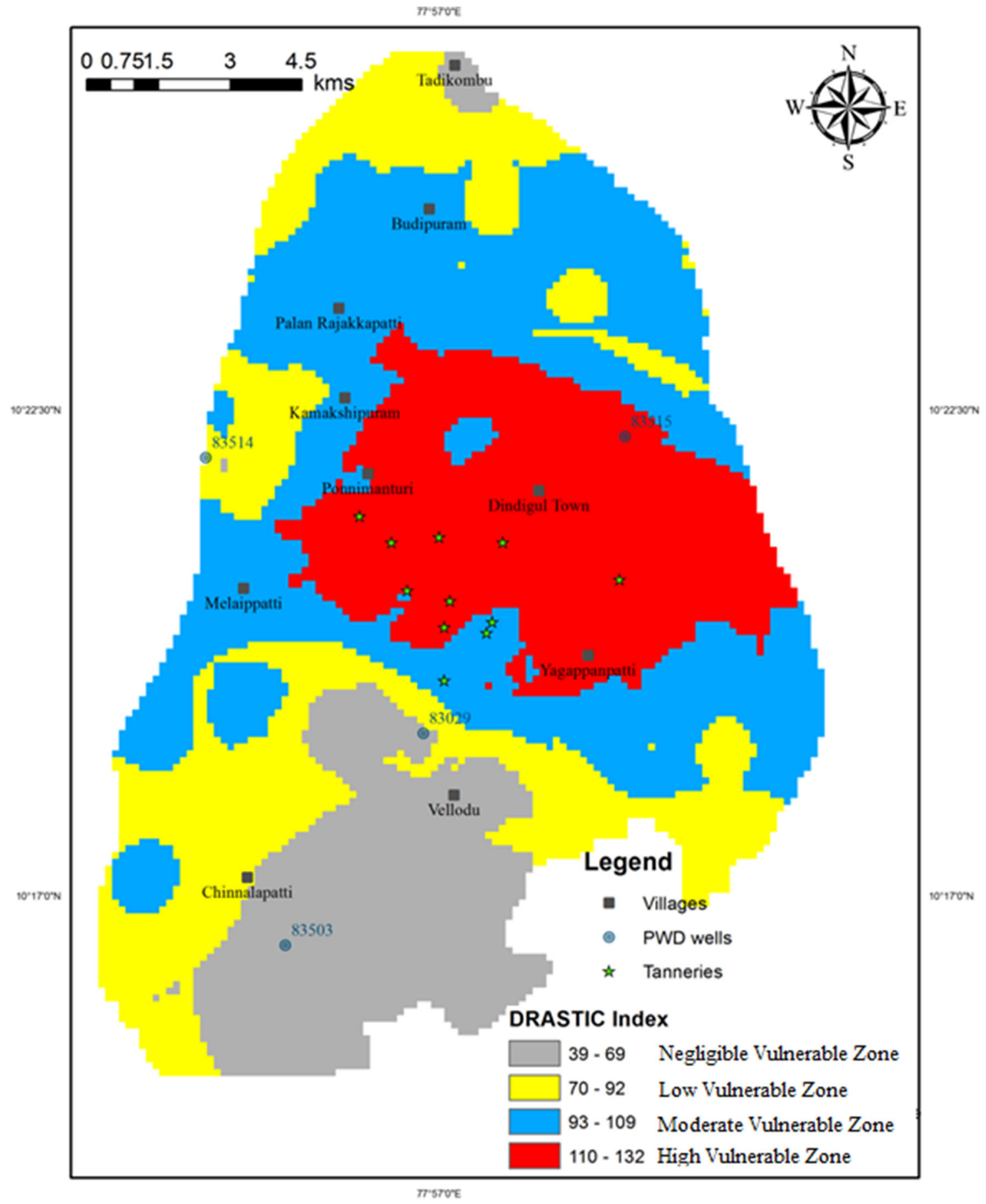

Figure 11. DRASTIC model for vulnerability assessment in the study area.

high-risk zones are present in middle part of the study area (red color zone) and also more extended towards the east. Because the geometry of shallow aquifer in weathered zone underlining bed rock elongated towards the east (Mondal and Ahmed 2015), the surface elevation and surface water flow directions are affecting shallow groundwater quality. The low risk to negligible risk zones are present in the lower half of the region.

\subsection{Sensitivity analysis of the DRASTIC model}

It is believed that the impact of errors or uncertainties of the individual parameters on the final output (Evans and Myers 1990; Rosen 1994) is limited. Here, an attempt is made to evaluate which parameter was more dominating in deciding the DRASTIC index, whether it was really necessary to use all the seven DRASTIC parameters to assess 
Table 3. Significance of relative classes for aquifer pollution vulnerability zone.

\begin{tabular}{|c|c|c|c|}
\hline $\begin{array}{l}\text { Vulnerability } \\
\text { class (s) }\end{array}$ & $\begin{array}{l}\text { Vulnerability } \\
\text { index }\end{array}$ & $\begin{array}{l}\text { Area covered } \\
\qquad\left(\mathrm{km}^{2}\right)\end{array}$ & Practical definition \\
\hline High & $110-132$ & 55.2 & $\begin{array}{l}\text { Vulnerable to most water pollutants with } \\
\text { relatively rapid impact in many pollution sce- } \\
\text { narios }\end{array}$ \\
\hline Moderate & $93-109$ & 81.6 & $\begin{array}{l}\text { Vulnerable to some pollutants, but only when } \\
\text { continuously discharged/leached }\end{array}$ \\
\hline Low & $70-92$ & 60.0 & $\begin{array}{l}\text { Only vulnerable to conservative pollu- } \\
\text { tants in long-term when continuously dis- } \\
\text { charged/leached }\end{array}$ \\
\hline Negligible & $69-39$ & 43.2 & $\begin{array}{l}\text { Confining beds present with negligible signif- } \\
\text { icant vertical groundwater flow }\end{array}$ \\
\hline
\end{tabular}

the vulnerability by performing model sensitivity analysis.

The master data of the DRASTIC parameters were first estimated to $\pm 2 \%$ up to $\pm 6 \%$ and the model was run to get the final DRASTIC map. As of first iteration, the depth to water table data varied by $\pm 2 \%$, keeping all the other parameters constant. The model was then run without changing the band interval. This procedure was repeated for the remaining five parameters except the soil media of the study area, in six iterations considering about $\pm 2 \%, \pm 4 \%$ and $\pm 6 \%$ changes of the individual original data, because the DRASTIC factors change widely in the study area. Thus, the sensitivity analysis had been performed by changing individual factors with $\pm 2 \%$ to $\pm 6 \%$ variation, keeping the overall changes remain about $5-6 \%$ of the realistic (field) observations to find out the impact of the individual factor on the DRASTIC model. Since the vadose zone map does not have admirable change in small interval, the influence of this parameter was nullified and ignored. Hence, in total 36 vulnerable maps were prepared from the master data and the sensitivity analysis of each parameter was calibrated by the pixel count. The sensitivity results are presented in table 4 . In case of negligible vulnerability, depth to water table has more sensitivity and second sensible parameter was recharge. The remaining parameters show less sensitivity. The same sequence is also observed in the cases of low and moderate vulnerability zones of the study area (table 4). The variation was found changed in case of high vulnerability zones. The sensibility of recharge is nullified as the depth to water table plays an important role in controlling the contamination of groundwater in the study area.

\subsection{Validation shallow aquifer vulnerability}

Hydrochemical parameters represent the hydrodynamic processes involved within an aquifer. The spatial variation of these parameters such as TDS and all major cations and anions along with their cumulative distribution were investigated to explore the relationship between the aquifer vulnerability and hydrochemical variations. In total, 3, 7, 6 and 9 groundwater samples were collected from negligible, low, moderate and high vulnerability zones, respectively, for assessing hydrochemical composition and hydrodynamic processes.

\subsubsection{General hydrochemistry}

Statistical parameters, including minimum, maximum, mean, and standard deviation, of different chemical constituents of the analyzed ground water samples $(\mathrm{N}=25)$ from the study area were computed, as shown in table 5. Comparison of hydrochemical data with the World Health Organization (WHO 1984) drinking water standards showed about $96 \%(\mathrm{~N}=24), 80 \%(\mathrm{~N}=20)$, $60 \%(\mathrm{~N}=15), 56 \%(\mathrm{~N}=14)$, and $8 \%(\mathrm{~N}=2)$ of the samples exceeded the guideline values for total dissolved solids (TDS: $500 \mathrm{mg} / \mathrm{l}$ ), sodium $\left(\mathrm{Na}^{+}: 200 \mathrm{mg} / \mathrm{l}\right)$, chloride $\left(\mathrm{Cl}^{-}: 200 \mathrm{mg} / \mathrm{l}\right)$, sulphate $\left(\mathrm{SO}_{4}^{2-}: 200 \mathrm{mg} / \mathrm{l}\right)$, and nitrate $\left(\mathrm{NO}_{3}^{-}: 45\right.$ $\mathrm{mg} / \mathrm{l}$ ), respectively. This indicates that groundwater quality has deteriorated significantly in the study area.

In general, the TDS and chloride ion $\left(\mathrm{Cl}^{-}\right)$are high in the contaminated water and relatively less in fresh groundwater (Saxena et al. 2003; Sarwade et al. 2007; Mondal and Singh 2011). However, 
Table 4. Showing (A) high, (B) moderate, (C) low, and (D) negligible vulnerability pixels by changing the DRASTIC parameter(s) in the study area.

\begin{tabular}{|c|c|c|c|c|c|c|}
\hline $\begin{array}{l}\text { Changing } \\
\text { factor(s) }\end{array}$ & $\begin{array}{c}\text { Depth to } \\
\text { water level }\end{array}$ & $\begin{array}{c}\text { Net } \\
\text { recharge }\end{array}$ & $\begin{array}{l}\text { Aquifer } \\
\text { media }\end{array}$ & Topography & $\begin{array}{c}\text { Impact of } \\
\text { vadose zone }\end{array}$ & $\begin{array}{l}\text { Hydraulic } \\
\text { conductivity }\end{array}$ \\
\hline \multicolumn{7}{|c|}{ (A) For high vulnerability zone } \\
\hline$-6 \%$ & 4881 & 2751 & 2419 & 2864 & 2771 & 2901 \\
\hline$-4 \%$ & 3473 & 2751 & 2419 & 2861 & 2771 & 2901 \\
\hline$-2 \%$ & 2718 & 2833 & 2504 & 2834 & 2764 & 2911 \\
\hline Field data & 2381 & 2381 & 2381 & 2381 & 2381 & 2381 \\
\hline $2 \%$ & 2221 & 2499 & 2869 & 2764 & 2628 & 2710 \\
\hline $4 \%$ & 2133 & 2805 & 2967 & 2715 & 2769 & 2724 \\
\hline $6 \%$ & 2956 & 2885 & 2608 & 2670 & 2723 & 2923 \\
\hline \multicolumn{7}{|c|}{ (B) For moderate vulnerability zone } \\
\hline$-6 \%$ & 3093 & 5154 & 5566 & 5322 & 5363 & 5184 \\
\hline$-4 \%$ & 3694 & 5154 & 5566 & 5278 & 5363 & 5184 \\
\hline$-2 \%$ & 4374 & 5151 & 5521 & 5281 & 5381 & 5174 \\
\hline Field data & 3678 & 3678 & 3678 & 3678 & 3678 & 3678 \\
\hline $2 \%$ & 2991 & 3380 & 5296 & 5310 & 5420 & 5415 \\
\hline $4 \%$ & 2837 & 5394 & 5226 & 5336 & 5258 & 5413 \\
\hline $6 \%$ & 4095 & 5161 & 5450 & 5336 & 5392 & 5166 \\
\hline \multicolumn{7}{|c|}{ (C) For low vulnerability zone } \\
\hline$-6 \%$ & 1240 & 1845 & 1773 & 1733 & 1826 & 1709 \\
\hline$-4 \%$ & 1193 & 1845 & 1773 & 1733 & 1826 & 1697 \\
\hline$-2 \%$ & 1821 & 1818 & 1755 & 1724 & 1828 & 1704 \\
\hline Field data & 2666 & 2666 & 2666 & 2666 & 2666 & 2666 \\
\hline $2 \%$ & 3361 & 2857 & 1665 & 1726 & 1686 & 1778 \\
\hline $4 \%$ & 3533 & 1675 & 1645 & 1813 & 1674 & 1737 \\
\hline $6 \%$ & 1992 & 1829 & 1740 & 1716 & 1827 & 1751 \\
\hline \multicolumn{7}{|c|}{ (D) For negligible vulnerability zone } \\
\hline$-6 \%$ & 1383 & 794 & 760 & 732 & 672 & 706 \\
\hline$-4 \%$ & 436 & 794 & 760 & 732 & 672 & 765 \\
\hline$-2 \%$ & 1688 & 760 & 766 & 750 & 676 & 782 \\
\hline Field data & 1876 & 1876 & 1876 & 1876 & 1876 & 1876 \\
\hline $2 \%$ & 2028 & 1865 & 771 & 827 & 790 & 749 \\
\hline $4 \%$ & 2098 & 727 & 763 & 761 & 788 & 813 \\
\hline $6 \%$ & 1558 & 677 & 775 & 770 & 681 & 842 \\
\hline
\end{tabular}

bicarbonate $\left(\mathrm{HCO}_{3}^{-}\right)$is dominant in fresh groundwater than that of saline water. The molar ratio of $\mathrm{Cl}^{-} / \mathrm{HCO}_{3}^{-}$is referred to as the Revelle coefficient (Revelle 1941) and could be appraised as intensity of salinity into the shallow aquifer. Hence, these hydrochemical parameters have been used to verify the site-specific vulnerability towards shallow aquifer contamination.

The result shows that the samples that fall within the negligible vulnerable zones have comparatively low concentration of TDS (650-1389 $\mathrm{mg} / \mathrm{l}), \mathrm{Na}^{+}(47-161 \mathrm{mg} / \mathrm{l}), \mathrm{Cl}^{-}$(106-298 mg/l), $\mathrm{HCO}_{3}^{-}(340-500 \mathrm{mg} / \mathrm{l})$ and the molar ratios $\mathrm{Cl}^{-} /$ $\mathrm{HCO}_{3}^{-}$ranges from $0.54-1.03$. These values are relatively low in the southern and northern parts than other parts of the study area (table 5 , figure 12). In this area, the aquifers are found to have low vulnerability due to the subsequent replenishment of fresh water by infiltration from the Sirumalai Hill.

But the samples from the high vulnerable zones (in and around the tannery clusters) have high concentration of TDS $(2,304-39,100 \mathrm{mg} / \mathrm{l}), \mathrm{Na}^{+}(239$ $6,046 \mathrm{mg} / \mathrm{l}), \mathrm{Cl}^{-}(532-13,652 \mathrm{mg} / \mathrm{l})$, and the molar ratios $\mathrm{Cl}^{-} / \mathrm{HCO}_{3}^{-}$ranges from 1.43 to 106.81 . This area is highly susceptible to the advection of contaminants in the form of pollutants (Mondal and Singh 2012b). The moderate vulnerability conditions were observed around the highly vulnerable zones having a moderate hydrochemical concentrations of TDS (1204-3976 mg/l), Na+ (182-654 $\mathrm{mg} / \mathrm{l}), \mathrm{Cl}^{-}(213-1596 \mathrm{mg} / \mathrm{l})$, and the molar ratios 
Table 5. Minimum, maximum, mean and standard deviation of the selective groundwater samples for the study area in comparison with the worldwide average surface water and groundwater.

\begin{tabular}{|c|c|c|c|c|c|c|c|c|c|c|c|}
\hline Parameters & $\mathrm{pH}$ & $\mathrm{EC}$ & TDS & $\mathrm{Ca}^{2+}$ & $\mathrm{Mg}^{2+}$ & $\mathrm{Na}^{+}$ & $\mathrm{K}^{+}$ & $\mathrm{HCO}_{3}^{-}$ & $\mathrm{Cl}^{-}$ & $\mathrm{SO}_{4}^{2-}$ & $\mathrm{NO}_{3}^{-}$ \\
\hline \multicolumn{12}{|c|}{ Negligible vulnerability zone (sample nos. 3: 23, 20 \& 24) } \\
\hline Minimum & 7.05 & 1166 & 650 & 71 & 74 & 47 & 2 & 340 & 106 & 86 & 4 \\
\hline Maximum & 7.71 & 2170 & 1389 & 182 & 88 & 161 & 32 & 500 & 298 & 240 & 55 \\
\hline Mean & 7.42 & 1763 & 1103 & 120 & 82 & 112 & 12 & 440 & 224 & 145 & 21 \\
\hline Std. Dev. & 0.33 & 528 & 396 & 57 & 7.3 & 59 & 17 & 87 & 103 & 83 & 29 \\
\hline \multicolumn{12}{|c|}{ Low vulnerability zone (sample nos. $7: 2,6,8,17,10,22 \& 25$ ) } \\
\hline Minimum & 7.56 & 780 & 499 & 56 & 22 & 43 & 2 & 214 & 57 & 25 & 2 \\
\hline Maximum & 8.25 & 2640 & 1796 & 173 & 110 & 295 & 16 & 420 & 418 & 290 & 10 \\
\hline Mean & 7.91 & 1478 & 935 & 111 & 48 & 123 & 5 & 312 & 227 & 96 & 4.5 \\
\hline Std. Dev. & 0.23 & 684 & 476 & 42 & 31 & 90 & 5.1 & 60 & 161 & 91 & 3.4 \\
\hline \multicolumn{12}{|c|}{ Moderate vulnerability zone (sample nos. 6: 1, 3, 7, 11, 18 \& 21) } \\
\hline Minimum & 7.31 & 1854 & 1204 & 83 & 31 & 182 & 2 & 280 & 213 & 110 & 5 \\
\hline Maximum & 8.24 & 5912 & 3976 & 433 & 176 & 654 & 12 & 520 & 1596 & 263 & 15 \\
\hline Mean & 7.79 & 3441 & 2341 & 223 & 93 & 354 & 6.1 & 376 & 807 & 192 & 8.1 \\
\hline Std. Dev. & 0.32 & 1750 & 1241 & 134 & 61 & 172 & 3.3 & 84 & 605 & 64 & 3.6 \\
\hline \multicolumn{12}{|c|}{ High vulnerability zone (sample nos. 9: 4, 5, 9, 10, 12, 13, 14, 15 \&16) } \\
\hline Minimum & 6.44 & 3300 & 2304 & 161 & 73 & 239 & 6 & 200 & 532 & 254 & 6 \\
\hline Maximum & 8.23 & 54000 & 39100 & 2490 & 1854 & 6046 & 62 & 640 & 13652 & 7154 & 87 \\
\hline Mean & 7.54 & 10626 & 7732 & 587 & 319 & 1160 & 16 & 375 & 2641 & 1149 & 18 \\
\hline Std. Dev. & 0.51 & 16414 & 11894 & 733 & 580 & 1859 & 17 & 164 & 4189 & 2257 & 26 \\
\hline \multicolumn{12}{|l|}{ Standards } \\
\hline For PLDW & $6.5-8.5$ & - & 500 & 75 & 30 & 200 & 100 & 200 & 200 & 200 & 45 \\
\hline For SW & - & - & - & 13.4 & 3.4 & 5.2 & 1.3 & - & 5.8 & 8.3 & - \\
\hline For GW & - & - & - & 50 & 7 & 30 & 3 & - & 20 & 30 & - \\
\hline
\end{tabular}

All ions in mg/l except EC in $\mu \mathrm{S} / \mathrm{cm}, \mathrm{pH}:-\log _{10} \mathrm{H}^{+}$; collected 25 groundwater samples on February 2009. PLDW: Permissible limit for drinking water (WHO 1984); SW: average surface water after Meybeck (1979) and GW: average groundwater after Turekian (1977).

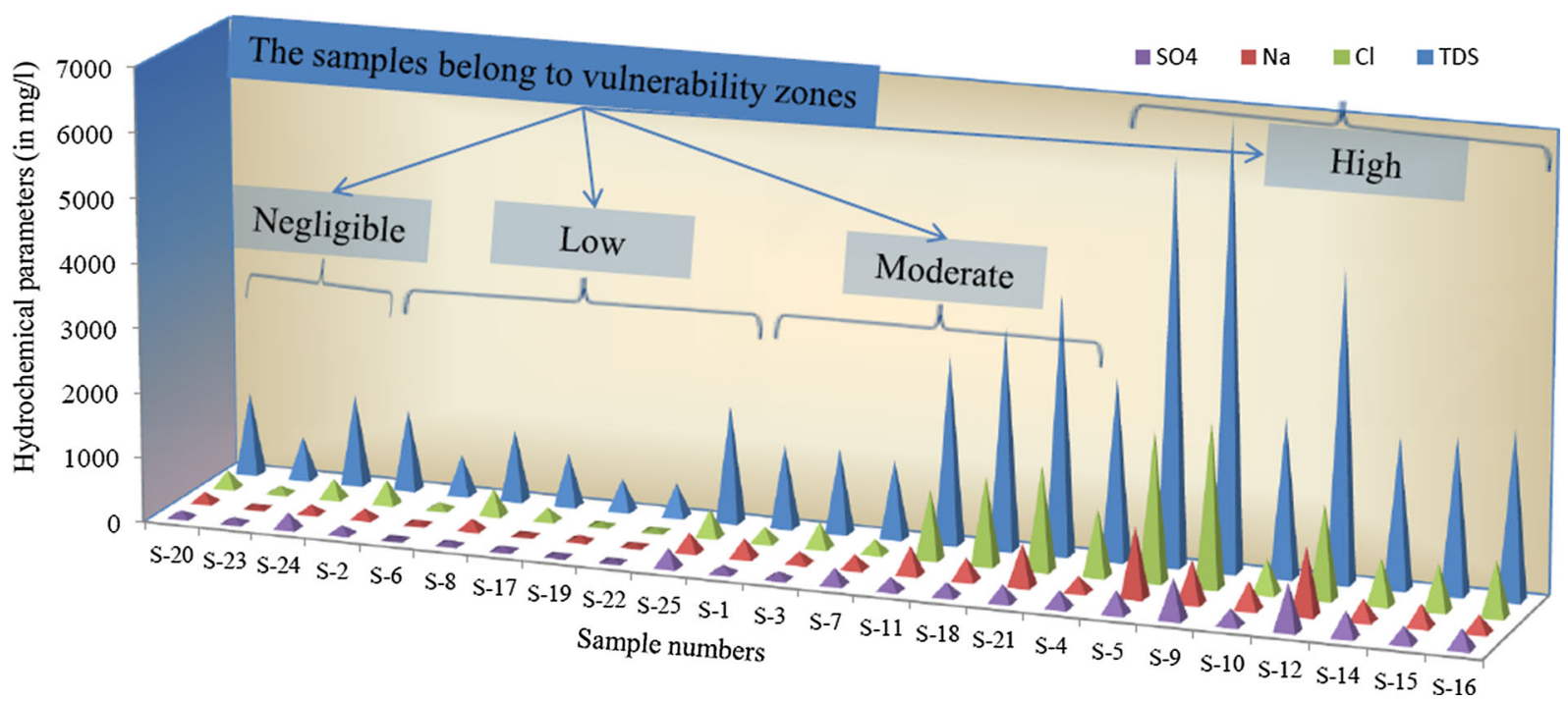

Figure 12. Comparative values of $\mathrm{SO}_{4}^{2-}, \mathrm{Na}^{+}, \mathrm{Cl}^{-}$and TDS (in mg/l) in the groundwater samples for the negligible, low, moderate and high vulnerability zones (except sample no. 13).

$\mathrm{Cl}^{-} / \mathrm{HCO}_{3}^{-}$ranges from $0.77-8.28$. The $\mathrm{SO}_{4}^{2-}$ concentration ranges from 110 to $263 \mathrm{mg} / \mathrm{l}$ and the $\mathrm{NO}_{3}^{-}$concentration ranges between 5 and $15 \mathrm{mg} / \mathrm{l}$, indicating comparatively fair groundwater quality. The movement of groundwater is slower in the black cotton soil area due to poor porosity and 
permeability. It reduces the groundwater flow and thus groundwater contamination (Mondal and Singh $2012 \mathrm{~b}$ ). The comparatively lower values of TDS (499-1796 mg/l) and $\mathrm{Cl}^{-}$(57-418 mg/l) were noticed in the northern and southern parts of the study area which is underlain by the low vulnerable zones.

\subsubsection{Cumulative probability distribution for, hydrochemical processes}

Most of the hydrochemical parameters obtained in this study exhibited log-normal density distributions. It is noticed that $\mathrm{Na}^{+}, \mathrm{Cl}^{-}$and $\mathrm{SO}_{4}^{2-}$ were major constituents of the tannery effluent, because leather industries use various chemicals like sodium carbonate, sodium bicarbonate, sodium chloride $(\mathrm{NaCl})$, chrome sulphate, etc., in the study area (Mondal and Singh 2010). However, the occurrence of an anomalous population as a 'tail' on the distribution suggested that groundwater chemistry was controlled by several intermixing processes. The frequency plots of $\mathrm{Na}^{+}, \mathrm{Cl}^{-}$and
$\mathrm{SO}_{4}^{2-}$ concentrations including TDS showed a log-normal distribution, but had a tail at high concentration ranges. In the study area, the regional background values of TDS, $\mathrm{Na}^{+}, \mathrm{Cl}^{-}$and $\mathrm{SO}_{4}^{2-}$ were about $1200,165,190$ and $69 \mathrm{mg} / \mathrm{l}$, respectively. This indicated that several numbers in the samples with high $\mathrm{Na}^{+}, \mathrm{Cl}^{-}$and $\mathrm{SO}_{4}^{2-}$ concentrations can be attributed to an anomalous population whose chemistry was locally affected by the effluent water mixing and others in the high vulnerability zone.

Cumulative probability distributions of TDS, $\mathrm{Na}^{+}, \mathrm{Cl}^{-}$and $\mathrm{SO}_{4}^{2-}$ are shown in figure 13(ad). There are 2-4 individual intersection points on the cumulative probability plots, which can be considered as regional threshold values and highly impacted threshold values for differentiating the samples with the effects of geogenic, anthropogenic and saline water mixing from the untreated effluents. The first approximate regional threshold values obtained were $1200 \mathrm{mg} / \mathrm{l}$ for TDS, $165 \mathrm{mg} / \mathrm{l}$ for $\mathrm{Na}^{+}, 190 \mathrm{mg} / \mathrm{l}$ for $\mathrm{Cl}^{-}$, and 69 $\mathrm{mg} / \mathrm{l}$ for $\mathrm{SO}_{4}^{2-}$ (figure 13). Broadly, the samples
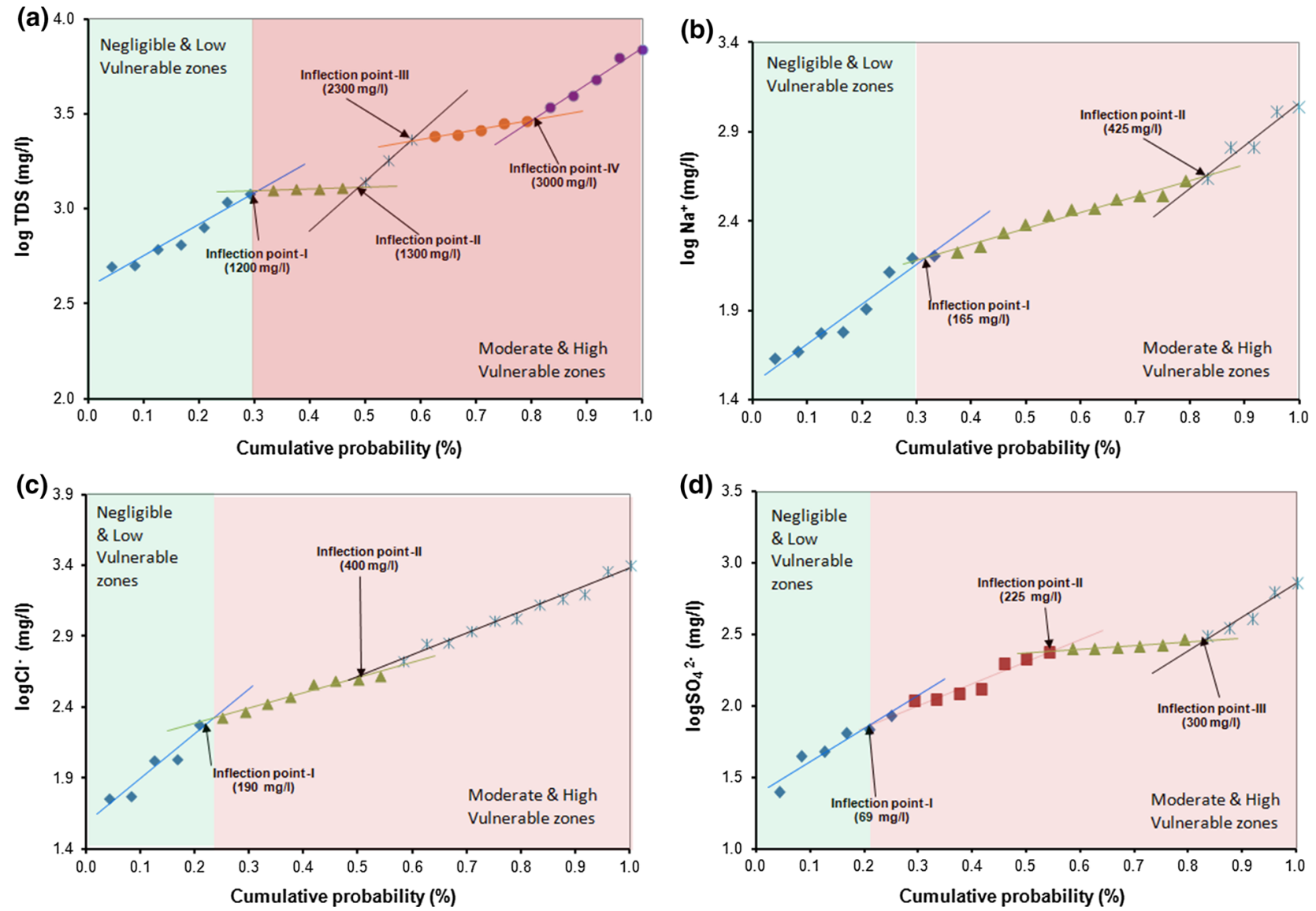

Figure 13. Cumulative probability distribution of TDS, $\mathrm{Na}^{+}, \mathrm{Cl}^{-}$and $\mathrm{SO}_{4}^{2-}$ (in $\mathrm{mg} / \mathrm{l}$ ) for the groundwater samples in the negligible, low, moderate and high vulnerability zones (except sample no. 13). 
have less than the first threshold values of these hydrochemical parameters fallen in the negligible and less vulnerability zones in the study area. Simultaneously, the second estimated highly impacted threshold values were 1300, 425, 400 and $225 \mathrm{mg} / \mathrm{l}$ for TDS, $\mathrm{Na}^{+}, \mathrm{Cl}^{-}$, and $\mathrm{SO}_{4}^{2-}$, respectively. The samples located in the moderate and highly vulnerability zones, fallen on the third segment for the $\mathrm{Na}^{+}, \mathrm{Cl}^{-}$, and $\mathrm{SO}_{4}^{2-}$ concentrations but in the 2-4th segments of TDS on the cumulative probability curves. These were highly affected by the tannery effluents. The five samples have fallen on the last segments for $\mathrm{Na}^{+}, \mathrm{Cl}^{-}$, and $\mathrm{SO}_{4}^{2-}$ concentration and the 4th segment for the TDS within the high vulnerable zones which are mainly located in and around the tannery clusters. These have been recorded with high concentration of TDS (3976-6895 mg/l), $\mathrm{Na}^{+}(434-1,090 \mathrm{mg} / \mathrm{l})$, $\mathrm{Cl}^{-}(1347-2517 \mathrm{mg} / \mathrm{l})$, and $\mathrm{SO}_{4}^{2-}(310-721 \mathrm{mg} / \mathrm{l})$. It shows that the cumulative probability distribution of the hydrochemical parameters directly indicate the vulnerability zones for the shallow aquifer in the hard rock area.

\section{Conclusions}

An attempt has been made to assess the shallow aquifer vulnerability using DRASTIC index in a granitic terrain of southern India. The results show that about $43 \%$ of the area is healthy with little vulnerability. The remaining $57 \%$ of the area is highly polluted. This is mainly because of the tannery industries which release untreated waste water into the ground. The pollution has also reached to the surrounding agricultural farms hence polluting the land as well as the production coming from the land. The sensitivity analysis of the DRASTIC model has resulted in delineating high vulnerability zones where the depth to water table is a driving force for controlling the groundwater contamination.

The hydrochemical parameters such as TDS, $\mathrm{Cl}^{-}, \mathrm{HCO}_{3}^{-}, \mathrm{SO}_{4}^{2-}$ and $\mathrm{Cl}^{-} / \mathrm{HCO}_{3}^{-}$molar ratios have been analyzed to verify the efficiency of the vulnerability. The samples falling in the high vulnerable zone have been recorded with high concentration of TDS (2304-39,100 mg/l), $\mathrm{Na}^{+}$(239-6046 $\mathrm{mg} / \mathrm{l}), \mathrm{Cl}^{-}(532-13,652 \mathrm{mg} / \mathrm{l})$, and the molar ratios $\mathrm{Cl}^{-} / \mathrm{HCO}_{3}^{-}$ranges from $1.43-106.81$. The low concentrations of TDS (650-1389 mg/l), $\mathrm{Na}^{+}(47-161$ $\mathrm{mg} / \mathrm{l}), \mathrm{Cl}^{-}(106-298 \mathrm{mg} / \mathrm{l}), \mathrm{HCO}_{3}^{-}(340-500 \mathrm{mg} / \mathrm{l})$ and the molar ratios $\mathrm{Cl}^{-} / \mathrm{HCO}_{3}^{-}(0.54-1.03)$ are observed within the negligible vulnerable zone(s).

The cumulative probability distributions of TDS, $\mathrm{Na}^{+}$, and $\mathrm{Cl}^{-}$constituents show 2-4 individual intersection points on the cumulative probability plots. The concentrations of TDS, $\mathrm{Na}^{+}$, and $\mathrm{Cl}^{-}$ in groundwater in the negligible vulnerable zone are found to be in the first regional threshold values obtained as $1200 \mathrm{mg} / \mathrm{l}$ for TDS, $165 \mathrm{mg} / \mathrm{l}$ for $\mathrm{Na}^{+}$, and $190 \mathrm{mg} / \mathrm{l}$ for $\mathrm{Cl}^{-}$, whereas the second threshold values, 1300,425 , and $400 \mathrm{mg} / 1$ for TDS, $\mathrm{Na}^{+}$, and $\mathrm{Cl}^{-}$, respectively, in the high vulnerable zone. The hydrochemical results are found to be well correlated with the DRASTIC model in the study area. Hence, the vulnerability assessment through the DRASTIC model in any hydrogeological system along with hydrochemical signatures is important for sustainable groundwater management.

\section{Acknowledgements}

The authors are thankful to Dr. V M Tiwari, Director of CSIR-NGRI, Hyderabad, India who has encouraged and given the permission to publish this article. The work has been carried out under the NGRI-CSIR In-House Project (MLP-6407). They also thank the two anonymous reviewers for their constructive comments to improve the article.

\section{References}

Akhtar M M and Tang Z 2014 Evaluation of local groundwater vulnerability based on DRASTIC index method in Lahore, Pakistan; Geofisica Int. 54(1) 67-81.

Albinet M and Margat J 1970 Cartographie de la vulnéra bilité à la pollution des nappes d'eau souterraines. (Mapping aquifer vulnerability to pollution) in French; Bull. BRGM 2(3-4) 13-22.

Aller L, Bennet T, Leher J H, Petty R J and Hackett G 1987 DRASTIC: A standardized system for evaluating groundwater pollution potential using hydrogeological setting; EPA 600/2-87-035 622.

Al-Rawabdeh AM 2013 GIS-based DRASTIC model for assessing aquifer vulnerability in Amman-Zerqa groundwater basin, Jordan; J. Sci. Res. 5 490-504.

Bai L, Wang Y and Meng F 2012 Application of DRASTIC and extension theory in the groundwater vulnerability evaluation; Water Environ. J. 2(3) 381-391.

Brindha K and Elango L 2015 Cross comparison of five popular groundwater pollution vulnerability index approaches; J. Hydrol. 524 595-613.

Browen E, Skougstad M W and Fishman M J 1970 Method for collection and analysis of water samples for dissolved mineral and gasses; US Govt. Printing Office, Washington. 
Evans BM and Myers W L 1990 A GIS-based approach to evaluating regional groundwater pollution potential with DRASTIC; J. Soil Water Conserv. 45(2) 242-245.

Insaf S B, Mohamed A A M, Tetsuya H and Kikuo K 2005 A GIS-based DRASTIC model for assessing aquifer vulnerability in Kakamigahara Heights, Gifu Prefecture, central Japan; Sci. Total Environ. 345(1-3) 127-140.

Iqbal J, Pathak G and Gorai A K 2015 Development of hierarchical fuzzy model for groundwater vulnerability to pollution assessment; Arab J. Geosci. 8 2713-2728.

Javadi K N 2011 Modification of DRASTIC model to map groundwater vulnerability to pollution using nitrate measurements in agricultural areas; J. Agri. Sci. Tech. 13 239-249.

Kaliraj S, Chandrasekar N, Simon Peter T, Selvakumar S and Magesh N S 2015 Mapping of coastal aquifer vulnerable zone in the south west coast of Kanyakumari, south India, using GIS-based DRASTIC model; Environ. Monit. Assess. 1874073.

Khan A, Khan H H, Umar R and Khan M H 2014 An integrated approach for aquifer vulnerability mapping using GIS and rough sets: Study from an alluvial aquifer in north India; Hydrogeol. J. 22 1561-1572.

Kim Y J and Hamm S 1999 Assessment of the potential for groundwater contamination using DRASTIC/EGIS technique, Cheonghu area, South Korea; Hydrol. J. 7 227-235.

Kumar P, Debnath S K, Thakur P K and Bansod B K S 2016 Assessment of the effectiveness of DRASTIC in predicting the vulnerability of groundwater to contamination: A case study from Fatehgarh Sahib district in Punjab, India; Environ. Earth Sci. $\mathbf{7 5} 879$.

Kumar S, Thirumalaivasan D and Radhakrishnan N 2014 GIS based assessment of groundwater vulnerability using drastic model; Arab J. Sci. Eng. 39 207-216.

Lathamani R, Janardhana, M R, Mahalingam B and Suresha S 2015 Evaluation of aquifer vulnerability using Drastic Model and GIS: A case study of Mysore City, Karnataka, India; Aquatic Procedia 4 1031-1038.

Mamadou S and Zhonghua T 2010 Assessment of groundwater pollution potential of the Datong Basin, northern China; J. Sust. Dév. 3(2) 140-152.

Mehra M, Oinam B and Singh C K 2016 Integrated assessment of groundwater for agricultural use in Mewat district of Haryana, India using geographical information system (GIS); J. Indian Soc. Remote Sens. 44(5) 747-758.

Meybeck M 1979 Concentrations des eaux fluviales en elements majeurs et apports en solution aux oceans; Rev. Geol. Dyn. Geogr. Phys. 21 215-246.

Mondal N C and Ahmed S 2015 Dar-Zarrouk parameters for deducing shallow fresh groundwater zones in a tannery belt, Tamil Nadu, India; J. Geophys. 36(4) 175-185.

Mondal N C and Singh V P 2010 Need of groundwater management in tannery belt: A scenario about Dindigul town, Tamil Nadu; J. Geol. Soc. India 76(3) 303-309.

Mondal N C and Singh V P 2011 Hydrochemical analysis of salinization for a tannery belt in southern India; $J$. Hydrol. 405(2-3) 235-247.

Mondal N C and Singh V P 2012a Evaluation of groundwater monitoring network of Kodaganar River basin from southern India using entropy; Environ. Earth Sci. 66(4) 1183-1193.
Mondal N C and Singh V P 2012b Chloride migration in groundwater for a tannery belt in southern India; Environ. Monit. Assess. 184(5) 2857-2879.

Mondal N C and Singh V S 2004 A new approach to delineate the groundwater recharge zone in hard rock terrain; Curr. Sci. 87(5) 658-662.

Mondal N C and Singh V S 2005 Modeling for pollutant migration in the tannery belt, Dindigul, Tamilnadu, India; Curr. Sci. 89(9) 1600-1606.

Mondal N C, Saxena V K and Singh V S 2005 Assessment of groundwater pollution due to tanneries in and around Dindigul, Tamilnadu, India; Environ. Geol. 48(2) 149 157.

Mondal N C, Singh V P, Singh S and Singh V S 2011 Hydrochemical characteristic of coastal aquifer from Tuticorin, Tamil Nadu, India; Environ. Monit. Assess. 175(1-4) 531-550.

Mondal N C, Singh V P and Ahmed S 2012 Entropy-based approach for assessing natural recharge in unconfined aquifers from southern India; Water Res. Manag. 26(9) 2715-2732.

Mondal N C, Bhuvaneswari Devi A, Anand Raj P, Ahmed S and Jayakumar K V 2016a Estimation of aquifer parameters from surfacial resistivity measurement in granitic area in Tamil Nadu; Curr. Sci. 111(3) 524-534.

Mondal N C, Tiwari K K, Sharma K C and Ahmed S 2016b A diagnosis of groundwater quality from a semiarid region in Rajasthan, India; Arab. J. Geosci. 9(12) 1-22.

Moulton D L 1992 DRASTIC analysis of the potential for groundwater pollution in Pinal County, Arizona; Arizona Geological Survey, 11 Sheets, 67.

Prasad K and Shukla J P 2014 Assessment of groundwater vulnerability using GIS-based DRASTIC technology for the basaltic aquifer of Burhner watershed, Mohgaon block, Mandla (India); Curr. Sci. 107(10) 1649-1656.

Prasad R K, Mondal N C, Banerjee P, Nandakumar M V and Singh V S 2008 Deciphering potential groundwater zone in hard rock through the application of GIS; Environ. Geol. 55(3) 467-475.

Prasad R K, Singh V S, Krishnamacharyulu S K and Banerjee P 2011 Application of DRASTIC model and GIS: For assessing vulnerability in hard rock granitic aquifer; Environ. Monitor. Assess. 176 143-155.

Public Works Department (PWD) 2000 Groundwater perspective - a profile of Dindigul District, Tamilnadu. Chennai, India, 102p.

Revelle R 1941 Criteria for recognition of seawater in groundwaters; Trans. Am. Geophys. Union 22 593-597.

Rosen L 1994 A study of the DRASTIC methodology with emphasis on Swedish conditions; Ground Water 32(2) $278-285$.

Saha D and Alam F 2014 Groundwater vulnerability assessment using DRASTIC and Pesticide DRASTIC models in intense agriculture area of the Gangetic plains, India; Environ. Monit. Assess. 186 8741-8763.

Salwa S, Salem B and Hamed B D 2011 Sensitivity analysis in groundwater vulnerability assessment based on GIS in the mahdia-Ksour Essaf aquifer, Tunisia: A validation study; J. Hydrol. Sci. 56(2) 288-304.

Sarwade D V, Nandakumar M V, Kesari M P, Mondal N C, Singh V S and Bhoop Singh 2007 Evaluation of seawater 
ingress into an Indian Attoll; Environ. Geol. 52(2) 14751483.

Saxena V K, Singh V S, Mondal N C and Jain S C 2003 Use of hydrochemical parameters for the identification of fresh groundwater resources, Potharlanka Island, India; Environ. Geol. 44(5) 516-521.

Selvam S, Magesh N S, Sivasubramanian P, Manimaran G, Soundranayagam J P and Seshunarayana T 2014 Deciphering of groundwater potential zones in Tuticorin, Tamil Nadu, using remote sensing and GIS techniques; J. Geol. Soc. India 84 597-608.

Sinclair A J 1974 Selection of thresholds in geochemical data using probability graphs; J. Geochem. Explor. 3129 149.

Singh A, Srivastav S K, Kumar S and Chakrapani G J 2015 A modified-DRASTIC model (DRASTICA) for assessment of groundwater vulnerability to pollution in an urbanized environment in Lucknow, India; Environ. Earth Sci. $\mathbf{7 4}$ 5475-5490.

Singh V S, Mondal N C, Ron Barker, Thangarajan M, Rao T V and Subramaniyam K 2003 Assessment of groundwater regime in Kodaganar river basin (Dindigul district), Tamilnadu; Tech. Rept. No.-NGRI-2003-GW-269, p. 104.

Sinha M K, Verma M K, Ahmad I, Baier K, Jha R and Azzam R 2016 Assessment of groundwater vulnerability using modified DRASTIC model in Kharun Basin, Chhattisgarh, India; Arab J. Geosci. 998.

Srinivasamoorthy K, Vijayaraghavan K, Vasanthavigar M, Sarma V S, Rajivgandhi R, Chidambaram S, Anandhan P and Manivannan R 2011 Assessment of groundwater vulnerability in Mettur region, Tamilnadu, India using drastic and GIS techniques; Arab J. Geosci. 4 1215-1228.

Stigter T Y, Ribeiro L and Dill A 2006 Evaluation of an intrinsic and a specific vulnerability assessment method in comparison with groundwater stalinization and nitrate contamination levels in two agricultural regions in the South of Portugal; Hydrol. J. 14(1-2) 79-99.

Tennant C B and White M L 1959 Study of the distribution of some geochemical data; Econ. Geol. 54 1281-1290.

Tirkey K, Gorai A K and Iqbal K 2013 AHP-GIS based DRASTIC model for groundwater vulnerability to pollution assessment: A case study of Hazaribag district, Jharkhand, India; Int. J. Environ. Protec. 2(3) 20-31.

Tiwari A K, Singh P K and Maio M D 2016 Evaluation of aquifer vulnerability in a coal mining of India by using GIS-based DRASTIC model; Arab J. Geosci. 9438.

Turekian K K 1977 Geochemical distribution of elements; 4th edn, Encyclopedia of Science and Technology; McGrawHill, New York, 630p.

World Health Organization (WHO) 1984 Guideline of drinking quality; World Health Organization, Washington.

Corresponding editor: RAJIB MAITY 